\title{
A COMPARATIVE EXPOSITION OF THE LAW OF HUSBAND AND WIFE IN TERMS OF ISLAMIC LAW, SOUTH AFRICAN LAW AND THE LAW OF ENGLAND AND WALES - PART ONE
}

\author{
Razaana Denson \\ BA LLB HDE LLM LLD \\ Advocate of the High Court \\ Lecturer in Private Law \\ Nelson Mandela University
}

\section{SUMMARY}

The primary concern of this article is a comparative analysis of marriage law in three legal systems - namely, Islamic law, South African law and English law. The similarities and differences between these legal systems are highlighted. The comparative analysis demonstrates that although there are similarities in the three legal systems, the differences outweigh the similarities. This begs the question whether Islamic law (Muslim personal law in general and family law in particular) can be recognised and accommodated and implemented in the South African and English legal systems (both constitutional democracies) without compromising the principles of Islamic law, while at the same time upholding the rights contained in the Bill of Rights. To this end, a comparative analysis is undertaken of the law of marriage that entails a discussion, inter alia, of betrothal (engagement), the legal requirements for a marriage, as well as the personal and proprietary consequences of a marriage as applicable in Islamic law, South African law and English law.

Islamic law, South African law and English law view the institution of marriage as a social institution of vital importance and one which is entitled to legal protection. In terms of the Islamic religion, the only intimate relationship allowed between a man and a woman is the marriage relationship. ${ }^{1}$ Islam regards marriage not only as the lawful means for sexual enjoyment, but also as being essential for the establishment of the family, which is regarded as the first unit of society. ${ }^{2}$ The institution of marriage is

Alkhuli The Light of Islam (1981) 65

Ibid. 
the only lawful Islamic means by which a family comes into existence and is, therefore, strongly encouraged. ${ }^{3}$

Historically, the position in South Africa was that the traditional RomanDutch common-law marriage was regarded as being superior to other kinds of marriage existing in South Africa. ${ }^{4}$ After the enactment of the Constitution of the Republic of South Africa, 1996 (the Constitution), attempts were made to give legal support and protection to other forms of relationship that did not fall squarely into the common-law definition of marriage. ${ }^{5}$ As a result, the Constitution, and the Constitutional Court in particular, requires South African family law to accommodate and protect diversity; the Constitution affirms the right to be different, and also celebrates the diversity of South African society. ${ }^{6}$ In the present-day constitutional era, South African family law thus embodies a far wider range of family form, and the definition of a family now includes single-parent, ${ }^{7}$ extended, ${ }^{8}$ polygynous, unmarried and same-sex families.

In a similar vein, English law also attaches much importance to the institution of marriage as the State has always endorsed the institution of marriage by encouraging parties to enter into marriage. Unlike Islamic law, both English law and South African law recognise family units other than the traditional family. To this extent, as far as same-sex couples are concerned, English law has accommodated these diverse family forms with the enactment of legislation in the form of the Civil Partnership Act 2004 and the Marriages (Same Sex Couples) Act 2013.

The institution of marriage and the concept of family is of vital importance and worthy of protection in terms of Islamic, ${ }^{9}$ South African ${ }^{10}$ and English law. ${ }^{11}$ Islamic, South African and English law, furthermore, regard marriage as the institution that provides marriage partners with companionship, love, conjugal rights, comfort and loyalty to each other. In essence, when two parties enter into a marriage it is regarded as the uniting of two souls physically, mentally and emotionally. However, the main difference between these three legal systems is that South African and English family law has extended the definition of family to include diverse family forms and has

Siddiqi The Family Laws of Islam (1984) 28.

Seedat's Executors $v$ The Master 1917 AD 302.

Ss 10,15 and $28(1)$ of the Constitution provide constitutional protection for the family.

$6 \quad$ Minister of Home Affairs v Fourie (Doctors for Life International, Amici Curiae; Lesbian \& Gay Equality Project $v$ Minister of Home Affairs) 2006 (1) SA 524 (CC) par 60. See also the Recognition of Customary Marriages Act 120 of 1998 and the Civil Union Act 17 of 2006.

7 Hall and Wright In Brief: A Profile of Children Living in South African Using the National Income Dynamics Study (2011) 2.

8 Ibid.

9 Quran ch 7, verse 89; Quran ch 4v verse 34; Doi Shari'ah The Islamic Law (1984) 114.

10 South African Law Reform Commission Discussion Paper 104 Project 118 Domestic Partnerships (August 2003) 160; Lind "Sexual Orientation and the Transitional Constitution" 1995 SALJ 482; Mosikatsana "The Definitional Exclusion of Gays and Lesbians from Family Status" 1996 SALJ 557; Satchwell v President of the Republic of South Africa 2002 (9) BCLR 986 (CC).

11 Huang $v$ Secretary of State for the Home Department [2007] UKH L 11; [2007] 2 AC 167; Reece Divorcing Responsibility (2003) 106; Berger and Keller "Marriage and the Construction of Reality" 199946 Diogenes 1; Burton Family Law (2003) 13; Herring Family Law (2011) 39. 
granted legal protection to alternate family forms. This is not the position in Islamic law, which adopts a narrower approach to what constitutes the family. The differences between the three legal systems serve to highlight the different ideological principles on which Islamic law is premised in comparison to South African and English law. The comprehensive set of rules and principles developed by the three legal systems to regulate the institution of marriage, as well as betrothal or engagement, is now discussed.

\section{THE BETROTHAL OR ENGAGEMENT}

\section{Islamic law}

A betrothal (khitba), which precedes a marriage contract, is essentially composed of approaches made by the man (or his family) to the woman (or her family) asking for her hand in marriage, provided the proposed union is legally possible. ${ }^{12}$ However, nothing precludes a woman from making a proposal to a man. ${ }^{13}$ Terms and conditions are negotiated at this stage, and may end in mutual promises of marriage. ${ }^{14}$ Although highly recommended, the khitba is not a prerequisite for the conclusion of a valid marriage. The word "betrothal" is used, rather than "engagement", as it denotes a more conventional arrangement; unlike the latter, it does not per se entail a claim for damages in the event of a breach, as a betrothal is not regarded as a binding contract. ${ }^{15}$ The termination of an engagement without Shari'ahapproved justification is considered as breaking a promise, but Islamic law does not make provision for a claim for damages. The Permanent Committee for Islamic Rulings and Verdicts ${ }^{16}$ has stated that a betrothal between a man and a woman is not equivalent to a contract, and that either party may terminate the betrothal if they wish to do so, whether or not the other party agrees to termination of the betrothal. ${ }^{17}$

Both parties should be made aware of the circumstances of the other and should know the other's character and behaviour in order for betrothal to be valid. ${ }^{18} \mathrm{~A}$ betrothal is not permissible where there exists an impediment that prohibits a marriage from being concluded immediately. ${ }^{19}$ Furthermore, an engagement between a woman and a third party is not permitted where the woman is already engaged to someone else. ${ }^{20}$ However, if the proposal has

12 Bainham The International Survey of Family Law (1994) 3. In terms of Shari'ah, the parties do not have to be a specific age to enter into an engagement.

13 Nasseef Muhammad: Encyclopaedia of Seerah vol 2 (1982) 25. The Prophet Muhammad's (PBUH) first wife, Khadija, proposed to him. She was 40 years old at the time while the Prophet Muhammad (PBUH) was 25 years old.

14 Siddiqi The Family Laws of Islam 67.

15 Jamal The Status of Women Under Islamic Law and Modern Islamic Legislation (2009) 54.

16 This committee was established by royal decree on 29 August 1971 by King Faisal ibn Abd al-Aziz of Saudi Arabia.

17 Daweesh Fataawa al-Lajnah al-Daa'imah vol 18 (2003) 69.

18 Nasir The Status of Women Under Islamic Law and Modern Islamic Legislation (2009) 53.

19 Ba'-kathah Tuh-fatul Ikhwaan (1987) 143.

20 Alkhuli The Light of Islam 70. 
not yet been accepted or rejected, a third party can propose to the same person. ${ }^{21}$

In the selection of a marriage partner, a man or woman is allowed to select their marriage partner upon meeting and viewing the person. ${ }^{22}$ The parties are allowed to meet in the presence of a chaperone for a short period of time to become acquainted with each other's character, opinions and mannerisms. ${ }^{23}$ No courtship is allowed. ${ }^{24}$

According to the traditions of the Prophet Muhammad (PBUH), the man was encouraged to view the face and hands of a prospective bride before making a proposal of marriage. ${ }^{25}$ This is in conformity with the Islamic view that marriage is a contract and that the contracting parties must first view the subject matter of the contract. ${ }^{26} \mathrm{~A}$ woman is also not precluded from viewing a prospective husband. ${ }^{27}$ After the parties are satisfied with their selection of a marriage partner, a proposal of marriage is made. ${ }^{28}$ If the woman (or those representing her) accepts the man's offer of marriage, a betrothal takes place and it constitutes a reciprocated promise by the two parties to marry at some time in the future. ${ }^{29}$ After the conclusion of the betrothal, and once it becomes known that a woman is already betrothed, other men are precluded from proposing to the woman. ${ }^{30}$

It is customary for the prospective bride and bridegroom to exchange gifts and donations once the betrothal is formalised so as to strengthen the new relationship. ${ }^{31}$ The general rule with regard to the exchange of gifts is that it is haraam (unlawful) to demand the return of gifts and presents. ${ }^{32}$ The exception to the general rule arises where gifts are exchanged with a view to marriage. ${ }^{33}$ Where the marriage is not concluded, the gifts exchanged between the prospective groom and bridegroom must be returned if one of the parties requests the return of the gifts exchanged. ${ }^{34}$ The rationale for the exception is that the gifts were exchanged between the parties with a view to a marriage being concluded and were therefore not made gratuitously. ${ }^{35}$ Therefore, where a marriage is not concluded, Shari'ah makes it permissible

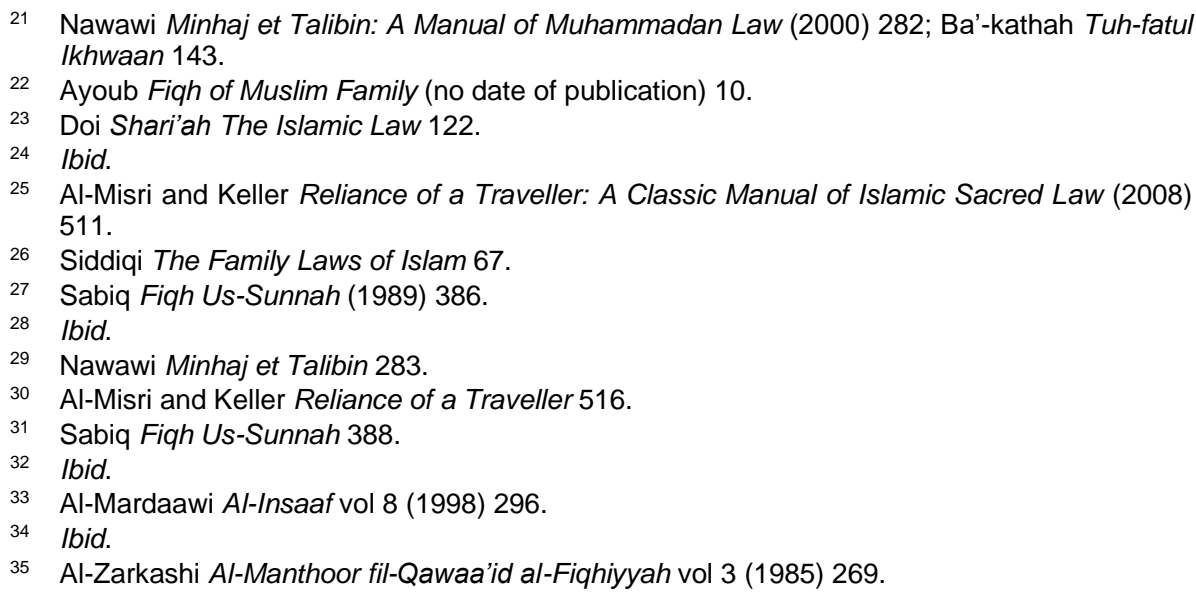


for the donor to demand the return of the gifts. ${ }^{36}$ Furthermore, where the gift has been damaged or where it has been depleted, it must be replaced. ${ }^{37}$

To summarise, the betrothal merely constitutes a mutual promise of marriage between the parties and does not constitute a marriage contract. Both parties are at liberty to withdraw from the betrothal at any stage before the conclusion of the marriage. ${ }^{38}$ The betrothal is also not legally binding between the parties in that it does not give rise to an action for breach of promise to marry. ${ }^{39}$ Insofar as the return of engagement gifts is concerned, a donor can claim the return of all gifts where a marriage is subsequently not concluded and this ruling applies irrespective of whether the gifts have been consumed or depleted.

\section{South African law}

According to common law, an engagement is defined as "a legally binding agreement, in the nature of a reciprocal promise or contract between a man and a woman (who are competent to marry) to marry each other on a specific date, or on some undetermined future date, but within a reasonable period". ${ }^{40}$ Since the enactment of the Civil Union Act ${ }^{41}$ same-sex partners are also allowed to enter into an engagement. An engagement has, therefore, in modern South African law, assumed the characteristic of being gender neutral.

An engagement, like any other contract, is concluded by means of offer and acceptance between the two parties concerned. ${ }^{42}$ Although an engagement precedes a marriage, it is not a prerequisite for the parties to enter into a valid civil marriage. ${ }^{43}$ As there are no special formalities required for the conclusion of an engagement, the engagement can be concluded orally, in writing or by mail or even tacitly. ${ }^{44}$ Because an engagement is regarded as a contract, in order to be regarded as legally binding, it must comply with four validity requirements laid down for valid contracts - namely, consensus, ${ }^{45}$ capacity to act, ${ }^{46}$ lawfulness ${ }^{47}$ and possibility of performance. ${ }^{48}$

The primary purpose of an engagement is for the parties to establish whether they are compatible and to foster a happy and successful marriage under the official protection of the law and within a socially acceptable

\footnotetext{
Ibn Taymiyah Al-Fataawa al-Kubra vol 5 (2010) 472.

Al-Jamal Sharh Manhaj al-Tullaab vol 4 (1938) 129.

Sabiq Fiqh Us-Sunnah 388.

Rautenbach and Bekker Introduction to Legal Pluralism 4ed (2014) 365.

40 Barratt, Domingo, Amien, Denson, Mahler-Coetzee, Olivier, Osman, Schoeman and Singh Law of Persons and the Family (2017) 227; Heaton and Kruger South African Family Law (1999) 5.

$41 \quad 17$ of 2006.

42 Heaton and Kruger South African Family Law 5.

43 Ibid.

44 Human, Robinson and Smith in Skelton and Carnelley (eds) Family Law in South Africa (2010) 20.

45 See Schnaar v Jansen 1924 NPD 218; Thelemann v Von Geyso 1957 (3) SA 39 (W).

46 S 26(1) of the Marriage Act 25 of 1961.

47 See Friedman v Harris 1928 CPD 43; Pietzsch v Thompson 1972 (4) SA 122 (R).

48 S 26(1) of 25 of 1961; s 18(3)(c)(i) read with ss 19 and 20 of the Children's Act 38 of 2005.
} 
environment. ${ }^{49}$ To this end, engaged parties enter into a courtship that will culminate in a marriage, provided they find that they are suited to each other. Where they are not compatible, the engagement will be terminated.

The fact that an engagement is a mutual undertaking by the two parties, to marry each other at a specific or determinable date, creates a reciprocal duty to marry on that date or on a date to be determined in the future. ${ }^{50}$ Should one of the parties to the engagement renege on the promise to marry, the party will be in breach of the contract of engagement. ${ }^{51}$ Withdrawal from the contract of engagement without potentially becoming liable for damages is only allowed if a iusta causa exists. ${ }^{52}$ In the absence of a iusta causa, the innocent party can sue the offending party for contractual as well as delictual damages arising out of the breach of promise to marry. ${ }^{53}$ With regard to the claim for contractual damages, only proved damages namely, patrimonial loss - can be claimed. ${ }^{54}$ Previously, patrimonial loss as well as proved prospective loss of the pecuniary benefits of the marriage could be claimed. 55

In addition to contractual damages, the innocent party can also bring a claim for damages for non-patrimonial loss under the actio iniuriarum for the infringement of personality rights. ${ }^{56}$ In order to succeed under the actio iniuriarium, the plaintiff is required to prove that his personal rights have been infringed and that the infringement was committed intentionally. ${ }^{57}$

During the course of the engagement, it is customary for the engaged parties to exchange various types of gift. Engagement gifts are classified into three categories - namely, sponsolatia largitas, which consist of gifts made with a view to the marriage; 58 arrhae sponsolatiae, which is a gift given to show the seriousness of the promise; ${ }^{\cdot 9}$ and lastly, other inconsequential gifts or tokens of affection. ${ }^{60}$ Where the engaged parties mutually decide to terminate the engagement, the sponsolatia largitas and the arrhae sponsolitiae must be returned. ${ }^{61}$ Where breach of promise has occurred, the innocent party is entitled to the arrhae sponsolatiae and sponsolatia largitas that he or she received or, alternatively, may recover these gifts if given to the guilty party. ${ }^{62}$ In the event of the innocent party instituting a claim for damages, the value of the gifts retained by the innocent party must be set off

49 Van Jaarsveld v Bridges 2010 (4) SA 558 (SCA) par 8.

50 Barratt et al Law of Persons and the Family 228; Sinclair The Law of Marriage (1996) 316.

51 Barratt et al Law of Persons and the Family 229.

52 See Van Jaarsveld $v$ Bridges supra par 3.

53 Barratt et al Law of Persons and the Family 229.

$54 \quad$ Van Jaarsveld $v$ Bridges supra par 2-7.

55 Guggenheim v Rosenbaum 1961 (4) SA 21. See Van Jaarsveld v Bridges supra and Cloete $v$ Maritz 2013 (5) SA 448 (WCC). It is submitted that the persuasiveness of the obiter dictum from the Van Jaarsveld case and the decision in Cloete will result in a denial of a claim for prospective loss.

Guggenheim v Rosenbaum supra 41; Van Jaarsveld v Bridges supra par 19.

57 Barratt et al Law of Persons and the Family 233.

58 For eg., appliances and furniture purchased for use in the future home.

59 The engagement ring is an example of arrhae sponsilitiae.

60 Flowers, chocolates and books are regarded as inconsequential gifts.

61 Voet 23.1.19; Barratt et al Law of Persons and the Family 234.

62 Heaton and Kruger South African Family Law 10. 
against the value of the damages claimed.63 Inconsequential gifts and tokens of affection need not be returned, irrespective of whether the engagement is terminated by mutual consent or whether breach of promise to marry occurs. ${ }^{64}$

\section{The law of England and Wales}

Before the conclusion of a marriage, it is common for couples to enter into an engagement in terms of which the parties agree to marry each other, either on a specified date or on some undetermined future date. ${ }^{65}$ In order for a valid engagement to be concluded, both parties must consent to the engagement, ${ }^{66}$ they must have legal capacity, ${ }^{67}$ the engagement must be lawful, ${ }^{68}$ and the parties must be in a position to conclude a valid marriage with each other. 69

The purpose of the engagement is to establish whether they are compatible to enter into a marriage that will be a lasting and happy one.

Common law regarded the engagement as an enforceable contract. If one of the parties terminated the engagement without iusta causa, the other party could institute an action for damages for breach of promise to marry. ${ }^{70}$ This position prevailed until 1970, when the action for breach of promise was abolished by section 1 of the Law Reform (Miscellaneous Matters) Act 1970, which states that no agreement to marry is enforceable as a contract. ${ }^{71}$ An ex-fiancé(e) does, however, have an action to recover any gift that was made on the express or implied condition that it would be returned should the marriage not occur. ${ }^{72}$ Furthermore, the presumption that the gift of the engagement ring is absolute can be rebutted by the giver producing evidence that it was in fact conditional. ${ }^{73}$

\section{Comparison}

From the discussion above it is clear that, while similarities exist between the Islamic law on betrothal and the South African law and English law on engagement, there are many distinct differences, especially in respect of the requirements necessary for a valid betrothal or engagement. This is problematic for South African and English Muslim women as they are confronted with two marriage systems that are at odds with one another namely, a religious and a secular legal system.

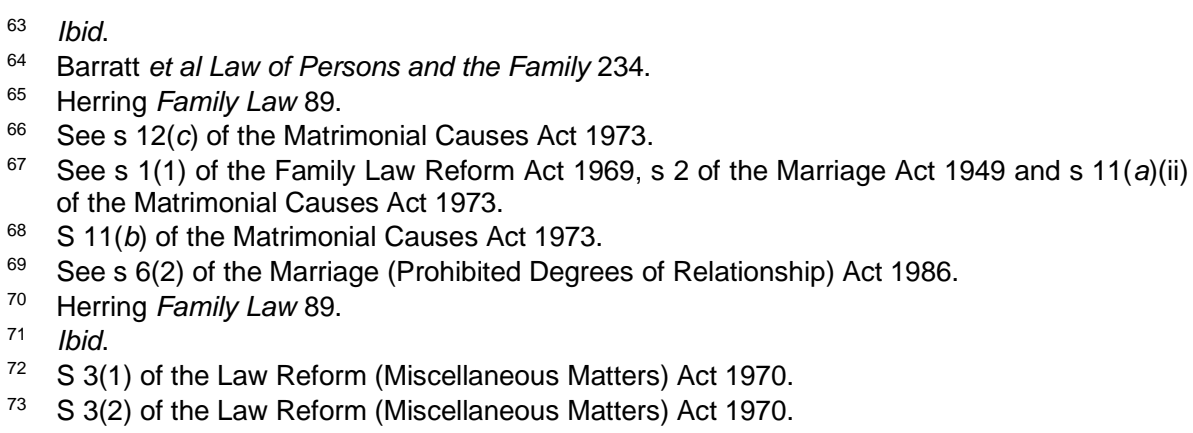


The similarities between a betrothal and an engagement relate to lawfulness, consent and capacity to act. In the laws of Islam, South Africa and England and Wales, an engagement is concluded by an offer (proposal) to marry and acceptance of the offer to marry. Secondly, the conclusion of a betrothal or an engagement is not a prerequisite for the conclusion of a valid marriage in any of the three legal systems under discussion. Thirdly, the parties cannot enter into a betrothal or engagement if they are related within the prohibited degrees of relationship. Fourthly, the consent of the prospective spouses is required in all three legal systems for a valid betrothal or engagement. Fifthly, both parties are also required to possess capacity to conclude a valid betrothal or engagement as the parties cannot enter into an engagement if one or both of them are under the age of puberty and both the prospective spouses must be immediately eligible to enter into a marriage. Lastly, as soon as the betrothal or engagement is concluded, the parties are expected to remain faithful to each other and not become intimately involved with third parties. In other words, both parties are expected to conduct themselves in a manner that will enhance and ensure a happy future marriage.

The notable differences between the legal systems are, first, the fact that an engagement in terms of both South African law and English law is very much a matter of individual concern, taking place between the prospective spouses, rather than being a family affair. Traditionally a man approaches the prospective bride's father or guardian for her hand in marriage, but he is under no legal obligation to do so. In contrast, an Islamic betrothal involves the families of the prospective bride and groom, with the groom's family approaching the prospective bride and her family with the proposal.

Secondly, notwithstanding that in all three legal systems both prospective spouses are required to consent to an engagement, Islamic law dictates that in addition, the consent of the prospective bride's guardian is required. This position prevails irrespective of whether or not the prospective bride is a major. In contrast, in both South African and English law, unless the prospective bride or groom is a minor, no parental or guardian consent is required for the conclusion of an engagement.

The third difference relates to the fact that, as Islam allows polygamy, a married man is allowed to propose marriage to a single woman. In South African and English law, both parties must be unmarried for an engagement to be valid.

The fourth difference pertains to the fact that in both South African and English law, the law relating to engagements is gender neutral, as the definition of an engagement can be extended to include an engagement concluded between same-sex couples. Islamic law only recognises betrothal between a man and a woman. Islamic law also differentiates between a man and woman in respect of the guardian's consent as the latter's consent is only required in respect of a male where the male is a minor. As stated above, the guardian's consent is required for a woman irrespective of whether she is a minor or major. 
Fifthly, Islamic law prohibits a betrothal with a woman who is in a period of $i d d a h^{74}$. In terms of South African and English law, a married spouse can enter into an engagement with a third person as soon as the marriage is dissolved by death or divorce. There are no legal impediments to a party proposing marriage to a third party once his or her marriage has been terminated.

The sixth difference between the three legal systems is that, in both South African and English law, the purpose of the engagement is to enable the couple to determine whether or not they are suited or compatible with each other with a view to creating a happy and successful marriage. In terms of Islamic law, the parties are allowed to meet and view each other at the time the proposal is made, but no courtship is allowed between the parties.

The seventh difference relates to the fact that, unlike the betrothal in terms of Islamic law, which is not regarded as a legally binding agreement and consequently does not give rise to an action for breach of promise to marry, an engagement in terms of South African law is a legally binding contract with legal consequences when breach of promise occurs. In terms of South African law, a breach of promise to marry gives rise to both a delictual and a contractual claim. Despite being regarded as a contract in terms of English law, an engagement nevertheless does not give rise to an action for damages if the engagement is terminated without iusta causa.

Lastly, in respect of gifts exchanged at the conclusion and during the subsistence of the betrothal and engagement, both Islamic law and South African law make provision for the return of such gifts where the betrothal or engagement is terminated. However, Islamic law differs in allowing for the return of gifts made with a view to the marriage, irrespective of which party is responsible for the non-conclusion of the marriage. Furthermore, Islamic law allows the parties to claim the return of gifts or the value thereof where the gifts have been depleted or consumed. In terms of South African law, the fate of the engagement gifts is determined by whether the engagement was terminated by mutual consent or whether breach of promise to marry occurred. South African law does not require parties to return gifts or the value that has already been consumed. In respect of English law, a gift can only be recovered if it was given on the express or implied condition that it would be returned should the engagement be terminated.

\section{DEFINITION OF MARRIAGE}

In this section, the definition of "marriage" in the three jurisdictions is compared in relation to potential spouses, impact of adultery and same-sex partners.

\section{Islamic law}

According to Ba'-kathah, marriage is defined as "a contract between two partners of the opposite sex, bringing about certain rights and

74 Iddah is the period of waiting or mourning which a widow or divorcee observes after the termination of the marriage either by death or divorce. 
responsibilities, whereby among other things, sexual relations is made permissible". ${ }^{75}$

The institution of marriage therefore has a three-fold function: first, the regulation of relations between a man and a woman; secondly, the regulation of relations between a child, his parents and the community; and lastly, it legalises sexual relations between a man and woman. ${ }^{76}$ It can be deduced from the definition that Islam regards fornication (zina) and samesex marriages as unlawful. ${ }^{77}$ Homosexuality and sexual relationships between same-sex parties are regarded as serious sins and contrary to Islamic principles and teachings. ${ }^{78}$ Islamic law, therefore, does not make any allowances for a marriage between same-sex partners.

\section{South African law}

Hahlo ${ }^{79}$ and Sinclair80 define marriage as "[t]he legally recognized voluntary union for life in common of one man and one woman, to the exclusion of all others while it lasts".

This definition of marriage as adopted by legal academics and the judiciary ${ }^{81}$ no longer holds true for modern South African society. This is evident from the high divorce rate, the tolerance of adultery, ${ }^{82}$ the fact that the Civil Union Act has granted legal recognition to marriages concluded by parties of the same sex, ${ }^{83}$ and the enactment of the Recognition of Customary Marriages Act, which legalises and recognises polygamous marriages. ${ }^{84} \mathrm{~A}$ more acceptable definition of a civil marriage in modern South African society would therefore be "the legally recognized voluntary union of two people to the exclusion of others while it lasts". 85

The decision in $R H \vee D E^{86}$ is testament to an increased tolerance of adultery as a result of changes in the mores of society. The decision in $R H V$ $D E$ changed the law relating to delictual action against a third party who commits adultery with one of the spouses in a marriage. Prior to the decision in $R H v D E$, the common law allowed both husbands and wives to institute a delictual claim against a third party who commits adultery with their spouses. ${ }^{87}$ The court held that in light of the changed mores of South African

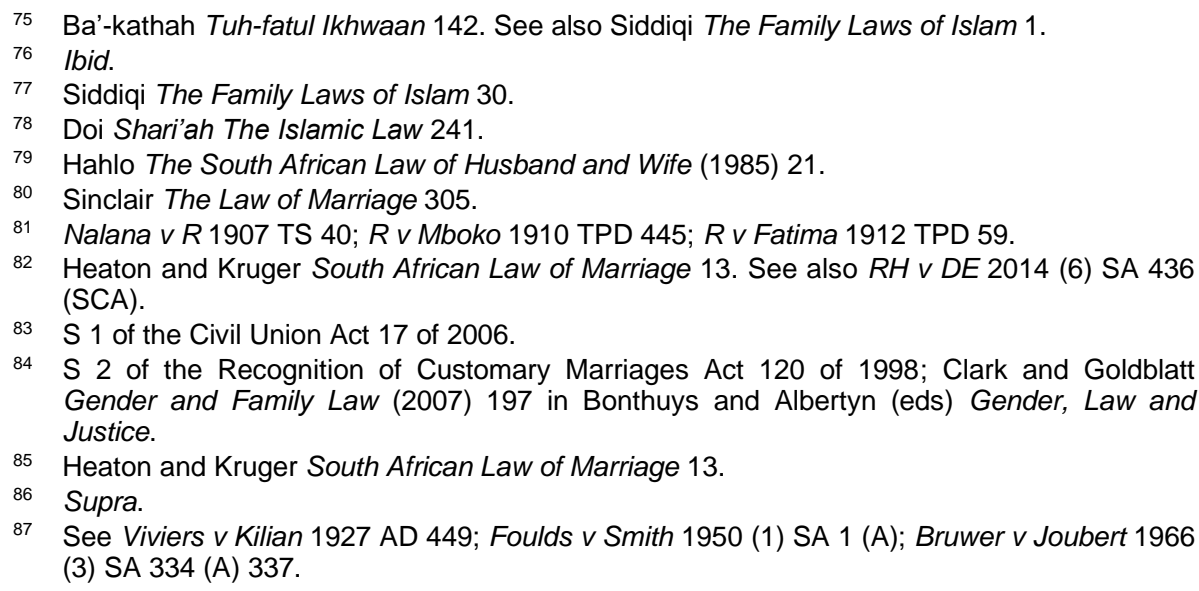

84 S 2 of the Recognition of Customary Marriages Act 120 of 1998; Clark and Goldblatt Gender and Family Law (2007) 197 in Bonthuys and Albertyn (eds) Gender, Law and Justice.

85 Heaton and Kruger South African Law of Marriage 13.

86 Supra.

87 See Viviers v Kilian 1927 AD 449; Foulds v Smith 1950 (1) SA 1 (A); Bruwer v Joubert 1966 (3) SA 334 (A) 337. 
society, the delictual claim for adultery has become outdated, and that the time has come for the action to be abolished. 88 It was held that the action derived from the actio iniuriarum based on adultery against third parties no longer forms part of South African law.

As stated above, the enactment of the Civil Union Act ${ }^{89}$ legalises civil unions between same-sex couples. ${ }^{90} \mathrm{~A}$ more acceptable definition of a civil marriage in modern South African society would therefore be "the legally recognized voluntary union of two people to the exclusion of others while it lasts". ${ }^{91}$ Mention must be made of the fact that the Civil Union Act extends to both heterosexual and same-sex couples.

Furthermore, the Recognition of Customary Marriages Act ${ }^{92}$ gives full recognition to all existing and future customary polygynous marriages, and allows a man to enter into multiple customary marriages provided he meets all the requirements set out in section 3(1) and section 7(6) of the Act.

\section{The law of England and Wales}

In Hyde $v$ Hyde and Woodmansee, ${ }^{93}$ the concept of marriage was defined as "the legally recognized voluntary union of a man and a woman for life to the exclusions of all others".

Although the definition of marriage, expounded by Lord Penzance in Hyde $v$ Hyde and Woodmansee, continues to be used by modern judges, it does not provide any criteria for distinguishing the institution of marriage from cohabitation. It is submitted that marriage should be defined as "a contract for which the parties elect but which is regulated by the State, both in its formation and in its termination by divorce, because it affects status upon which depend a variety entitlements, benefits and obligations". ${ }^{94}$ The definition distinguishes marriage from cohabitation as, unlike the latter, the law regulates a marriage from its inception until its termination. In addition, it creates a legal relationship with mutual rights and responsibilities. ${ }^{95}$

At present, the law of England and Wales legally recognises marriage in the forms of both civil and religious unions and marriages concluded in terms of the Marriages (Same Sex Couples) Act 2013. ${ }^{96}$ The definition of the term "marriage" in English law excludes polygamous marriages; a polygamous marriage between partners where one or both of them are domiciled in England and Wales is invalid.

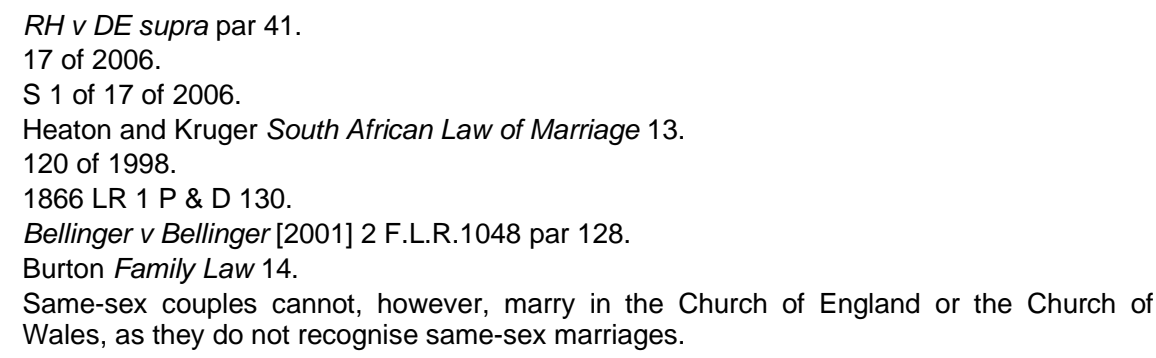


Adultery, alongside unreasonable behaviour, is one of the most widely used reasons for divorce in England and Wales. ${ }^{97}$

\section{Comparison}

All three legal systems view marriage as a contract that regulates the relationship between husband and wife, their children and society at large. South African and English law also regulates the relationship between married spouses and the State as a valid civil marriage or customary union can only take place with state endorsement and approval. This is not the position in terms of Islamic law. The Ulama (theologians), while professing to have moral authority over the Muslim community, can merely draw on the moral conscience of Muslim spouses to adhere to Shari'ah, but cannot compel compliance as their orders lack the force of law. The non-recognition and lack of regulation of Muslim marriages impacts severely on the parties to these marriages, particularly on women and children who, as vulnerable groups, are currently disadvantaged both on a social and economic level. The need for the enactment of legislation granting legal recognition to Muslim marriages is crucial. Having stated this, it is also imperative that any legislation enacted to recognise and regulate Muslim marriages be Shari'ah compliant.

Another significant difference between the three legal systems relates to one of the purposes or aims of a marriage concluded in terms of Islamic rites - namely, the legitimisation of sexual relations between the spouses. As mentioned previously, Islam prohibits any courtship or sexual relations before marriage. The institution of marriage is the only recognised institution in Islam that legitimises sexual relations between a man and a woman. Adultery is strictly prohibited and Islam has adopted a zero-tolerance policy in that respect. Besides regarding adultery as sinful, Islamic law has also criminalised it. In contrast, South African law has, as a result of the changing mores of society, become more tolerant of adultery. To this extent, adultery has been abolished as one of the grounds for divorce and, furthermore, as a result of changing societal attitudes in respect of adultery, a spouse can no longer bring a delictual claim against a third party who commits adultery with one of the spouses in a marriage. Adultery is still relevant as a factor in determining spousal maintenance and the division of matrimonial property particularly, in respect of forfeiture and redistribution orders. Insofar as English law is concerned, the presence of adultery is one of the facts that can be proved to establish that a marriage has indeed broken down.

Same-sex marriages are not recognised in Islam. Islam only grants recognition to a marriage between a man and a woman, as homosexuality ${ }^{98}$ is totally prohibited in terms of the Quran. ${ }^{99}$ In both South African and English legal systems, same-sex marriages have been legalised. If

97 In 1969, the Divorce Reform Act 1969 provided that irretrievable breakdown of the marriage was the sole ground for divorce. The laws regulating divorce have been consolidated in the Matrimonial Causes Act 1973.

98 Homosexuality includes gays, lesbianism, bisexuality and transgendered persons.

99 Al-Misri and Keller Reliance of a Traveller 664-665; Doi Shari'ah The Islamic Law 242-243. 
legislation is enacted to recognise Muslim marriages, that legislation would not allow same-sex marriages.

Unlike South African law ${ }^{100}$ and English law, Islam caters for polygamy, as provision is made for a man to have up to four wives at any given time. Legislation enacted to recognise Muslim marriages should include a provision regulating polygynous marriages. Although a man who wishes to enter into a polygynous marriage is not required to seek the consent of his wife (or anyone for that matter) in terms of Islamic law, the aspect of polygynous unions must be regulated to ensure fairness between all the wives and to ensure that the man is in a financial position to provide maintenance for all his wives as he bears the sole responsibility of maintenance during the subsistence of the marriage.

Notwithstanding these differences, all three legal systems view marriage, when it is regarded as lawful, as an institution that is of vital importance, and therefore affords greater legal protection and respect to marriage than it does to other informal intimate domestic relationships.

\section{THE LEGAL REQUIREMENTS FOR A VALID MARRIAGE}

This section will consider the legal requirements of a marriage in all three jurisdictions with specific reference to capacity, consent, lawfulness and formalities.

\section{Islamic law}

The Shafi'i school of jurisprudence prescribes the following requirements for the solemnisation of a marriage according to Muslim rites: the parties must possess capacity to marry each other; there must be consensus between the parties, and the guardian of the prospective bride must consent to the marriage; the marriage must be lawful; and lastly, the marriage must conform to certain formalities prescribed in terms of Shariah. ${ }^{101}$

\section{Legal Capacity}

In order for a valid marriage to be concluded, each of the parties must possess legal capacity. The marriage will be deemed void in the absence of legal capacity. Factors such as age and mental capacity affect the legal capacity of a person. ${ }^{102}$

\footnotetext{
100 The exception to this being the Recognition of Customary Marriages Act 120 of 1998, which allows the man to practise polygyny.

101 Doi Women in Shari'ah (1989) 48.

102 Rautenbach and Bekker Introduction to Legal Pluralism 366.
} 
(i)

Age

In terms of Islamic law, no particular age has been stipulated for marriage. ${ }^{103}$ Shari'ah allows for the conclusion of a marriage when the age of puberty (mukallaf or bulugh) is reached. ${ }^{104}$ Puberty is determined by signs of physical maturation or, where there is no declaration of puberty, there is a presumption that puberty has been reached, in the case of a girl, when she has reached the age of nine years and, in the case of a boy, when he has reached the age of twelve years. ${ }^{105}$ It is submitted that differing climatic, hereditary, physical and social conditions in different countries affect the age at which a person is deemed to be marriageable. As a result, no particular age is stipulated, as there would be a difference as to the marriageable age in different countries. ${ }^{106}$

In the event of a minor concluding a marriage, the consent of the minor (as well as the guardian of the minor) must be obtained. ${ }^{107} \mathrm{~A}$ minor who is given in marriage by his or her guardian without the minor's consent has the option of repudiating the marriage when reaching the age of majority. ${ }^{108}$ In contrast, the marriage of a minor without consent of the guardian is rendered voidable, and the validity of the marriage depends on whether the guardian will ratify the marriage. ${ }^{109}$

\section{(ii) Mental capacity}

The general rule in respect of a person who suffers from mental illness is that the person is allowed to conclude a marriage, subject to the condition that he or she informs the person he or she wishes to marry about the mental condition. ${ }^{110}$ Where a party accepts or indicates acceptance of the fact that his or her future spouse suffers from mental illness, the party loses the right to have the marriage annulled. ${ }^{111}$

According to the majority of Islamic jurists, mental illness renders a marriage null and void and the innocent spouse can have the marriage annulled if he or she had been unaware that the other party suffered from mental illness at the time that the marriage was concluded. ${ }^{112}$

Provision is also made for the guardian of a woman, or an Islamic judge, to grant consent on behalf of a mentally ill woman to enter into a marriage so as to protect her from having illicit sexual relations, provided a physician

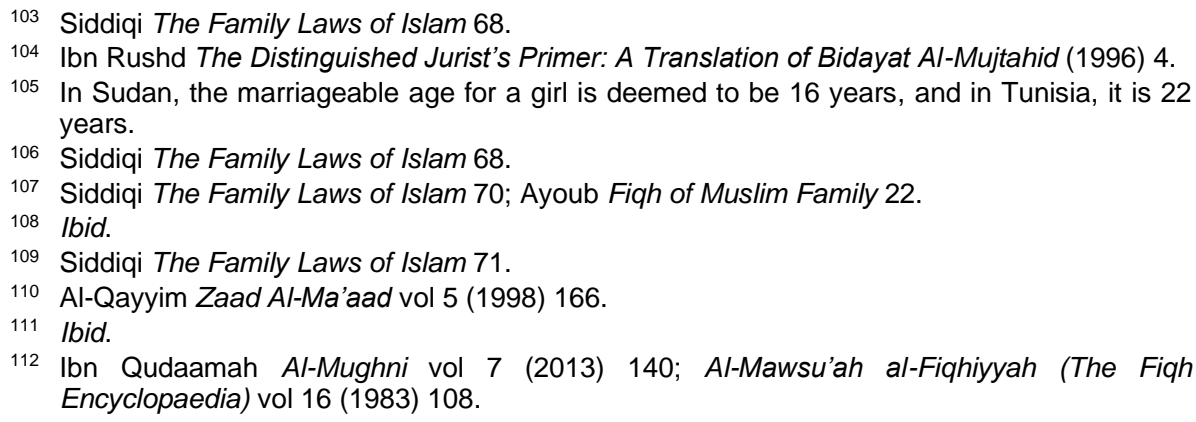


gives evidence that the marriage can cure the woman of her mental illness. ${ }^{113}$

\section{Consent}

\section{(i) The consent of the prospective groom and bride}

Both parties to the proposed marriage must have the intention to enter into a marriage with each other. ${ }^{114}$ Consent on the part of both parties constitutes an essential requirement for a valid marriage. ${ }^{115}$ Both the man and the woman have the freedom to choose their marriage partners. ${ }^{116}$ The parents or guardian of the parties cannot force them to enter into a marriage with a person whom they do not wish to marry. ${ }^{117}$ The parents or guardian can advise the parties contemplating marriage with regard to their choice of a marriage partner, but there is no justification for forced marriages in Islam. ${ }^{118}$ Where the parents or guardian effect a marriage of a woman to someone without obtaining her consent, the marriage is null and void. ${ }^{119}$

Where a woman is divorced or widowed, her consent must be obtained before a further marriage can be concluded. Whether or not a woman has been previously married, her consent has to be obtained in order for a valid marriage to be contracted.

(ii) The consent of the guardian of the prospective bride

A marriage contracted without the consent of the woman's guardian is invalid. ${ }^{120}$ Where a woman enters into married life without the permission of her guardian, the marriage is null and void. ${ }^{121}$ This is the view held by the majority of the schools of jurisprudence, except the Hanafi school of jurisprudence. ${ }^{122}$

In order for the guardian's consent to be valid, the guardian must be male, legally responsible, a Muslim of good moral character and of sound judgement. ${ }^{123}$ All the schools of jurisprudence, except the Hanafi school, are in agreement that the woman's guardian must be appointed from her paternal male family. ${ }^{124}$ The order of preference for the appointment of a

113 Ayoub Fiqh of Muslim Family 36.

114 Doi Shari'ah The Islamic Law 123.

115 Alkhuli The Light of Islam 70.

116 Doi Shari'ah The Islamic Law 123.

117 Siddiqi The Family Laws of Islam 69.

118 Alkhuli The Light of Islam 72. A marriage entered into under duress is null and void.

119 Ayoub Fiqh of Muslim Family 22.

120 Ayoub Fiqh of Muslim Family 26; Doi Shariah The Islamic Law 140.

121 Doi Shari'ah The Islamic Law 141.

122 Doi Shari'ah The Islamic Law 140. There are four schools of jurisprudence in Islam: Shafi'i, Hanafi, Maliki and Hanbali. The Hanafi school is of the opinion that it is permissible for a woman to enter into a marriage without the consent of her guardian.

123 Al-Misri and Keller Reliance of a Traveller 518.

124 Ayoup Fiqh of Muslim Family 29. 
guardian is as follows: first, her father, and then her grandfather or greatgrandfather if her father is deceased, and thereafter her brothers, brothers' sons or sisters' sons or father's brothers, and so on. ${ }^{125}$ The consent of the guardian is also required where a minor male wishes to enter into a marriage. ${ }^{126}$ According to the Shafi'i school of jurisprudence, only the father or grandfather of a minor will suffice as guardian to consent to the marriage of the minor. ${ }^{127}$

\section{Lawfulness}

Even if both parties to a prospective marriage possess the necessary capacity to act and do consent to the marriage, the marriage can be rendered void on the ground of unlawfulness, ${ }^{128}$ as, in terms of Islamic law, there must be no impediments to the marriage taking place. In this regard, the impediments ${ }^{129}$ prohibiting marriage may be divided into either permanent ${ }^{130}$ or temporary impediments. ${ }^{131}$

\section{Formalities}

\section{(i) Witnesses to the marriage}

For a marriage to be validly concluded, the presence of at least four people is required - namely, the guardian of the bride, the bridegroom or his representative and two witnesses. ${ }^{132}$ The witnesses are required to be just, free persons over the age of puberty who are not blind, deaf, mute or mentally ill. ${ }^{133}$ The presence of witnesses at the marriage ceremony is essential to ensure compliance with the publicity requirement. ${ }^{134}$ The presence of two males or one male and two female witnesses is required at the wedding ceremony. If both parties to the marriage are Muslim, then it is required for the witnesses to be Muslim as well.

(ii) Offer (ljab) and acceptance (qabul) of the marriage proposal

From a legal perspective, as in any other contract, a marriage contract (aqdun-nikah) can be concluded only through the pillars (arkan) of offer and

\footnotetext{
Siddiqi The Family Laws of Islam 71.

Siddiqi The Family Laws of Islam 73.

Doi Shari'ah The Islamic Law 142.

Doi Shari'ah The Islamic Law 124.

129 Rautenbach and Bekker Introduction to Legal Pluralism 366-367; Doi Women in Shari'ah 36.

130 For eg., a permanent impediment exists if parties are related within the prohibited degrees of relationship either by consanguinity, affinity or fosterage. Adoption is prohibited in terms of Islamic law.

131 For eg., a temporary impediment may exist in the face of a previous valid marriage, irrevocable divorce or where the parties follow different religions.

132 Ba'-kathah Tuh-fatul Ikhwaan 143.

134 Rautenbach and Bekker Introduction to Legal Pluralism 366.
}

133 Ibid. 
acceptance by the two principals or their proxies. ${ }^{135}$ There must be a meeting of minds by means of offer and acceptance. The proposal for marriage and acceptance thereof must be clearly conveyed, and there must be no room for ambiguity. ${ }^{136}$

\section{(iii) The parties must agree on the dowry}

Although all the major schools of jurisprudence are of the view that there must be agreement in respect of the dowry, an absence of agreement does not affect the validity of the marriage. ${ }^{137}$

\section{(iv) Publicity of the marriage}

The marriage must be publicised. ${ }^{138}$ The publicity requirement serves to differentiate the institution of marriage from mere fornication. ${ }^{139}$ The public announcement also serves to warn others not to interfere with the conjugal relations of the married couple. ${ }^{140}$ If no public announcement is made, or there are no witnesses present, the union between the parties merely amounts to fornication and not a marriage. ${ }^{141}$ This is the position even if both parties have consented to the marriage, as the factor that distinguishes a marriage from a clandestine relationship is its publicity. ${ }^{142}$

\section{Place of marriage}

It is not a prerequisite for the validity of a marriage, nor is it sunnah, ${ }^{143}$ for the marriage to be concluded in a mosque. ${ }^{144}$ It is, however, mustahab or desirable that the marriage be concluded in a mosque for the sake of the barakah (blessing) and also so that the marriage be made public. ${ }^{145}$

\section{Mustahab (Commendable) Acts}

In addition to the legal requirements that must be met for the marriage to be valid and enforceable, Islamic law also regards certain acts (discussed below), which are performed at the time that the marriage is concluded, to be mustahab or commendable acts. ${ }^{146}$

\footnotetext{
135 Ba'-kathah Tuh-fatul Ikhwaan 143. In terms of Islamic law, marriage by proxy is permissible whereby the woman delegates the conclusion of her marriage to her guardian. 


\section{(i) Khutbah (sermon)}

Before the marriage is announced, the Imam delivers a wedding sermon, whereby he advises both the prospective husband and wife on how they should conduct themselves as a married couple. ${ }^{147}$ Both parties are, furthermore, reminded of the rights and responsibilities they will have towards each other once they enter into a marriage. ${ }^{148}$ At the conclusion of the marriage sermon, an announcement is made that the parties have accepted each other as husband and wife. ${ }^{149}$ The Imam also announces the dower at the same time that the marriage is concluded. ${ }^{150}$

\section{(ii) The marriage feast (walima)}

The giving of a walima is a confirmed sunnah in Islam. ${ }^{151}$ After the marriage ceremony has been concluded, the bride is taken to her husband's home where the bridegroom hosts the walima. ${ }^{152}$ The wedding feast is celebrated in accordance with the traditions of the Prophet Muhammad (PBUH). ${ }^{153}$ The walima also serves as a means to fulfil the requirement that the marriage be made public. ${ }^{154}$

(iii) Announcing the marriage by beating the tambourine or drums (duffs)

In order for the marriage to be announced publicly, it is permissible to play the tambourine or beat the duffs. ${ }^{155}$

\section{South African law}

For the purposes of a comparative analysis, the legal requirements for a valid civil marriage in terms of South African law are discussed first, and thereafter the requirements of a marriage concluded in terms of English law are set out. In order for parties to enter into a valid civil marriage in terms of South African law, ${ }^{156}$ the following essential requirements must be met: the parties must have capacity to marry each other; there must be consensus between the parties; the marriage must be lawful; and lastly, the wedding ceremony must conform to the prescribed formalities as stipulated in the Marriage Act. ${ }^{157}$

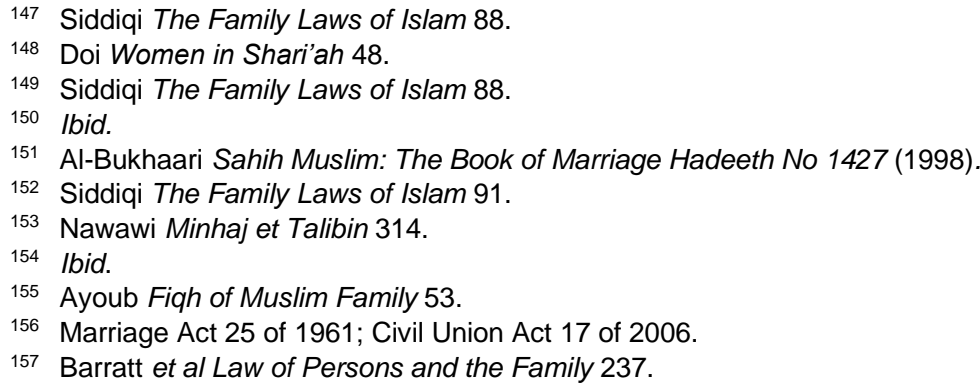




\section{Capacity to marry}

Owing to the fact that marriage is such an important juristic act, persons who are mentally ill and minors under the age of puberty are precluded from entering into a marriage as they have no capacity to marry. ${ }^{158}$

\section{(i) Age}

In terms of South African law, the age of puberty for girls and boys is set at 12 and 14 respectively. ${ }^{159} \mathrm{~A}$ child under the age of puberty has no capacity to enter into a marriage. ${ }^{160} \mathrm{~A}$ marriage concluded by a child below the age of puberty is void $a b$ initio and has no legal effect. Children over the age of puberty have capacity to enter into a civil marriage in terms of the Marriage Act, ${ }^{161}$ or a customary marriage in terms of the Recognition of Customary Marriages Act, ${ }^{162}$ provided the required legal consent has been obtained. ${ }^{163}$

Section 26(1) of the Marriage Act provides that, in addition to parental consent, ${ }^{164}$ the written consent of the Minister of Home Affairs is required where a girl between the ages of 12 and 15 and a boy between the ages of 14 and 18 wish to enter into a civil marriage. All minors below the age of 18 years, but over the age of puberty, require the written consent of the Minister of Home Affairs if they wish to enter into a customary marriage. ${ }^{165}$

The conclusion of a marriage terminates minority, and a minor who has been married before requires no consent to remarry. ${ }^{166}$

\section{(ii) Persons who are mentally ill}

The marriage of a person who is de facto mentally ill is void and of no legal effect. ${ }^{167}$ Owing to the highly personal nature of a marriage, a curator cannot consent to a marriage on behalf of a person who is mentally ill. ${ }^{168}$ This position prevails not only when the person is not able to understand the legal nature and consequences of the juristic act, but also when the person is influenced by hallucinations caused by mental illness. ${ }^{169}$ Certification that a person is mentally ill, and the appointment of a curator for the person, do not

158 Heaton and Kruger South African Family Law 14.

159 Nicholas An Introduction to Roman Law (2008) 91.

160 Sinclair The Law of Marriage 367.

16125 of 1961.

162120 of 1998

$163 \mathrm{~S} 24(1)$ of 25 of 1961 ; s 3(3) of 120 of 1998; s 1 of the Civil Union Act 17 of 2006. See s 18(3)(c)(i), read with s 18(5) of the Children's Act 38 of 2005; s 3(3)(a) of 120 of 1998, which regulates the consent by the guardian of the minor. See s 25(1) and (4) of 25 of 1961 and $s 3(3)(b)$, which regulates the circumstances where the guardian of the minor cannot consent to the marriage.

164 The consent of the Minister of Home Affairs is additional and cannot therefore replace the consent of the parents, guardians, commissioner or that of the High Court.

$165 \mathrm{~S} 3(1)(\mathrm{a})(\mathrm{i})$ read with $\mathrm{s} 3(4)(a)$ of 120 of 1998.

$166 \mathrm{~S} 24(2)$ of 25 of 1961.

167 Barratt et al Law of Persons and the Family 238.

168 Lange $v$ Lange 1945 AD 332.

169 Ibid. 
per se affect the person's capacity to act. ${ }^{170}$ Whether or not a person is mentally ill is a question of fact. A marriage concluded when a mentally ill person experiences a lucidum intervallum - that is, a temporary period of sanity - is valid and enforceable. ${ }^{171}$ Certification is important as far as the onus of proof is concerned. Where a person has been declared mentally ill, the burden of proof is on that person to prove that he or she is not mentally ill. ${ }^{172}$ In contrast, in the absence of any certification, it is the person who alleges mental illness who bears the onus of proving the mental illness. ${ }^{173}$

\section{Consensus}

A valid marriage can only come into existence if both parties give voluntary informed consent to the marriage. ${ }^{174}$ During the marriage ceremony, the marriage officer must expressly ask both parties whether they accept each other as husband and wife. ${ }^{175}$ The parties are then required to answer in the affirmative if they wish to get married. ${ }^{176}$ The marriage officer is not allowed to solemnise the marriage if one of the parties is absent or replies in the negative. ${ }^{177}$ There are certain factors that negate consensus - namely, material mistake, ${ }^{178}$ misrepresentation ${ }^{179}$ and duress. ${ }^{180}$

\section{Lawfulness}

\section{(i) Prohibited degrees of relationship}

Persons who are too closely related, whether by consanguinity, ${ }^{181}$ affinity ${ }^{182}$ or adoption, ${ }^{183}$ may not marry each other. ${ }^{184}$

\section{(ii) An existing civil or customary marriage or civil union}

In terms of the Marriage Act ${ }^{185}$ and Civil Union Act, ${ }^{186}$ parties are prohibited from marrying each other where one or both of them are already married to

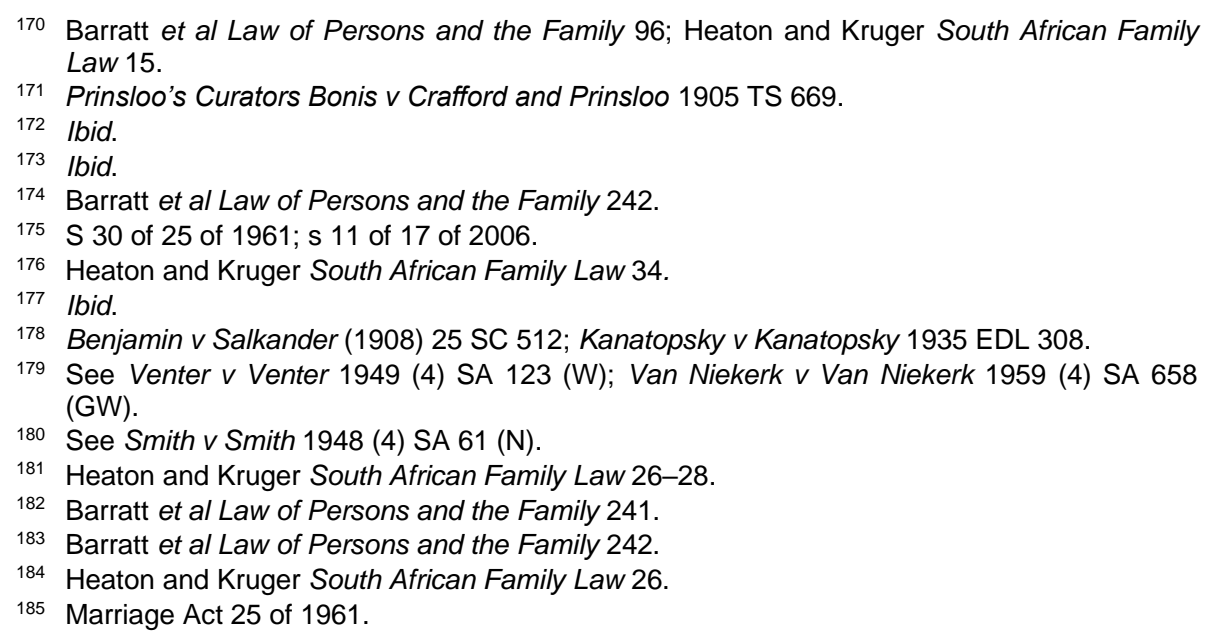


someone else or have entered into a civil union, ${ }^{187}$ or are married to someone else in terms of customary law. ${ }^{188}$ In other words, polygynous marriages are not allowed when parties enter into a civil marriage or union. ${ }^{189}$

Where a married person purports to enter into another civil marriage, the second marriage will be unlawful and void and therefore have no legal effect. ${ }^{190}$ In this instance, the person will have committed the crime of bigamy. ${ }^{191}$ However, where a married spouse believed in good faith that he or she was divorced while this was not the case, or where the unmarried spouse was oblivious of the other spouse's existing civil marriage, the marriage will be putative ${ }^{192}$ and as a result will be void. ${ }^{193}$

\section{(iii) Persons of the same sex}

The Civil Union Act ${ }^{194}$ permits same-sex partners as well as partners of the opposite sex to enter into a civil union. Civil marriages in terms of the Marriage Act, ${ }^{195}$ however, are reserved for heterosexual couples. ${ }^{196}$ In terms of customary law, parties of the same sex cannot enter into a customary marriage.

\section{Prescribed formalities}

The Marriage Act and the Civil Union Act set out almost identical formalities for the ceremony that must be met for the marriage to be valid. Noncompliance with these requirements will result in the marriage being rendered void. ${ }^{197}$

\section{(i) Witnesses}

Owing to the requirement that a marriage "be undertaken in a public and formal way", 198 section 29(2) of the Marriage Act and section 10(2) of the Civil Union Act require the presence of the prospective spouses and two

$86 \mathrm{~S} 8(2)$ of the Civil Union Act 17 of 2006.

187 This is a common rule set out by Grotius 1.5.2; Voet 23.2.1 and other Roman-Dutch writers.

188 Ss 3(2) and 10(4) of 120 of 1998.

189 The Recognition of Customary Marriages Act does make provision for polygynous marriages.

190 Grotius 2.5.2.

191 Barratt et al Law of Persons and the Family 239; Heaton and Kruger South African Family Law 26.

192 See Prinsloo v Prinsloo 1958 (3) SA 759 (T); Moola v Aulsebrook No 1983 (1) SA 687 (N).

193 Barratt et al Law of Persons and the Family 255; Heaton and Kruger South African Family Law 26. See Ngubane v Ngubane 1983 (2) SA 770 (T) and Solomons v Abrams 1991 (4) SA $437(\mathrm{~W})$

19417 of 2006.

19525 of 1961.

196 W v W 1976 (2) SA 308 (W); Simms v Simms 1981 (4) SA 186 (D).

197 Minister of Home Affairs v Fourie (Doctors for Life International, Amici Curiae; Lesbian \& Gay Equality Project $v$ Minister of Home Affairs) supra.

198 Minister of Home Affairs v Fourie (Doctors for Life International, Amici Curiae; Lesbian \& Gay Equality Project $v$ Minister of Home Affairs) supra par 64. 
competent witnesses at the time that the marriage is solemnised. Marriage by proxy is no longer permitted and the parties must be personally present at the solemnisation of their marriage. ${ }^{199}$

\section{(ii) Place and time of the wedding}

In terms of section 29(2) of the Marriage Act and section 10(2) of the Civil Union Act, a marriage can be solemnised in a public office or private dwelling-house; or a church or other building used for religious service. These sections, however, do not prohibit a marriage officer from solemnising a marriage in another place provided there are valid reasons for solemnisation occurring in that place. ${ }^{200} \mathrm{~A}$ marriage may be solemnised on any day of the week between the hours of eight in the morning and four in the afternoon. ${ }^{201}$

\section{(iii) Marriage officers}

In terms of section 11(2) of the Marriage Act and section 4 of the Civil Union Act, only a duly appointed marriage officer may solemnise a marriage. The marriage will be deemed to be void if this requirement is not met. ${ }^{202}$

\section{(iv) Objections}

In terms of section 23 of the Marriage Act and section 9 of the Civil Union Act, any objections to the proposed marriage must be lodged with the marriage officer who will solemnise the marriage. The marriage officer is under an obligation to investigate the basis of the objection, and can solemnise the marriage only once it is established that there is no lawful impediment to the proposed marriage. ${ }^{203}$

\section{(v) Proof of age and identity}

Before a marriage officer can solemnise the marriage, both parties to the proposed marriage must produce their identity document and the prescribed affidavit. 204

\section{(vi) The marriage formula}

In order for a marriage to be solemnised, it is essential that the marriage officer ask each of the parties whether there is any legal impediment preventing them from entering into the marriage, and whether he or she is prepared to accept the other as his or her lawfully wedded wife or husband

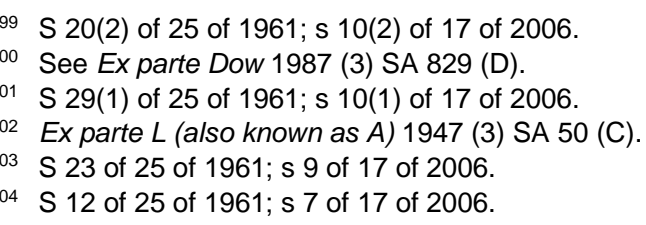


respectively. 205 The parties must reply in the affirmative in order for the wedding to proceed. ${ }^{206}$ After replying in the affirmative, the marriage officer will request that the parties give each other the right hand, whereupon the marriage officer will declare them husband and wife. ${ }^{207}$ It is at this moment that the marriage comes into existence. ${ }^{208}$

\section{(vii) Registration of the marriage}

Section 29A of the Marriage Act, section 12 of the Civil Union Act and section $4(3)(b)$ of the Recognition of Customary Marriages Act describe the essential elements of the registration of a marriage as being: first, the signing of the marriage register or other prescribed documents by the marriage officer, the parties to the marriage and the two competent witnesses; and secondly, the marriage register or other prescribed documents must be forwarded to a regional or district representative of the Department of Home Affairs. Non-registration of the marriage does not affect the validity of the marriage. ${ }^{209}$

\section{The law of England and Wales}

The legal requirements for a marriage to be valid in terms of English law are discussed next.

\section{Capacity}

Capacity to marry can affect the individual210 as well as the couple. ${ }^{211}$ Where the parties conclude a marriage without possessing the necessary capacity, the marriage will be deemed to be void.

(i) Age

Section 1(1) of the Family Law Reform Act 1969, section 2 of the Marriage Act 1949 and section 11(a)(ii) of the Matrimonial Causes Act 1973 provide that both parties must be 16 years or older to conclude a valid marriage. This is an absolute restriction, and a marriage involving a party younger than 16 years old will therefore be deemed to be void, even where a person believed in good faith that he or she had attained the required age. In terms of section 3 of the Marriage Act 1949, the consent of the parent or guardian in whom parental rights and responsibilities are vested is required in the event of the marriage of a 16 or 17 -year-old minor. ${ }^{212}$ Where a parent or

205 Hutchison, Van Heerden, Visser and Van der Merwe Willie's Principles of South African Law (1991) 107.

$206 \mathrm{~S} 30(1)$ of 25 of 1961 ; s 11(2) of 17 of 2006.

207 lbid.

208 Heaton and Kruger South African Family Law 32.

209 Ibid.

210 See Probert Family and Succession Law in England and Wales (2013) 72.

211 Ibid.

212 The Family Reform Act 1969 changed the age of majority from 21 to 18 years. 
guardian refuses to consent to an impending marriage, or is unable to give the consent by reason of absence, inaccessibility or disability, the consent of the court may replace the consent of the parent or guardian. ${ }^{213}$

\section{(ii) Mental capacity}

The Mental Capacity Act 2005 provides the statutory framework for persons who lack capacity to make decisions for themselves as a result of mental illness. The issue of incapacity owing to mental illness is specific both to the particular decision and to the time at which the decision is taken. A mentally ill person lacks capacity to enter into a legally binding marriage. ${ }^{214}$ Therefore, a marriage concluded by a person who is suffering from a mental disorder ${ }^{215}$ at the time the marriage is concluded is rendered voidable. ${ }^{216}$ In contrast, a marriage entered into by a mentally ill person during a lucidum intervallum is valid. In terms of section 27(1) of the Mental Capacity Act 2005, the court and/or any individual (including a parent) cannot in any circumstances give consent to marriage on behalf of an adult who lacks the capacity to give his/her own consent.

\section{Consent}

The enactment of the Nullity of Marriage Act 1971 provides that a marriage concluded after 31 July 1971 would be voidable in the absence of true consent. ${ }^{217}$ The Matrimonial Causes Act 1973 recognises duress, mistake, unsoundness of mind and certain others ${ }^{218}$ as the circumstances that vitiate consent and therefore render the marriage voidable.

\section{Lawfulness}

\section{(i) Prohibited degrees of relationship}

Section 6(2) of the Marriage (Prohibited Degrees of Relationship) Act 1986 regulates the prohibited degrees of relationship by consanguinity, affinity 219 and adoption;220 marriages entered into within the prohibited degrees of relationship are deemed to be void. ${ }^{221}$

\footnotetext{
213 S 3 of the Marriage Act 1949. See Cretney, Mason and Bailey-Harris Principles of Family Law (2003) 12.

214 Re Beaney [1978] 1 W.L.R. 770.

215 As defined by the Mental Health Act 1983.

216 Bennett $v$ Bennett [1969] 1 All ER 539; S 12(c) Part II Ch 1 par 199 of the Matrimonial Causes Act 1973; s 50(1)(a) Part II Ch 2 par 234 of the Civil Partnership Act 2004.

217 S 12(c) of the Matrimonial Causes Act 1973.

218 The Matrimonial Causes Act refers to factors other than duress and mistake - for example, drunkenness, fraud and misrepresentation.

219 Marriage Act 1949, Sch.1 Pt II; Probert Family and Succession Law in England and Wales 73

220 Marriage Acts 1949-986, Sched. 1, Pt 1; S 47(1) of the Adoption Act 1976.

221 S 11(a)(i) of the Matrimonial Causes Act 1973; s 1 of the Marriage Act 1949.
} 


\section{(ii) Existence of a valid marriage}

Section 11(b) of the Matrimonial Causes Act 1973 prohibits a person from entering into a marriage with a third party where he or she is already married or is in a civil partnership with someone else. This prohibition is absolute. Where parties enter into a marriage in contravention of this absolute prohibition, they will be guilty of the crime of bigamy. A prior marriage or civil partnership always renders a later marriage void. ${ }^{222}$

(iii) Persons who are of the same sex

As indicated previously, the enactment of the Marriage (Same-Sex Couples) Act 2013 legalised same-sex marriages in England and Wales.

\section{Formalities of marriage}

The three key stages to the solemnisation of a marriage insofar as the formalities are concerned are preliminaries, celebration and registration. ${ }^{223} \mathrm{~A}$ failure to observe the required formalities can, but does not necessarily, render the marriage void. ${ }^{224}$ If the parties knowingly and wilfully choose not to comply with the formalities as set out in the Marriage Act 1949, the marriage is deemed to be void.

(i) Preliminaries

(1) Parental consent

The issue of parental consent for the marriage of minors has already been mentioned under 431 (i) of this article.

Publicising the intention to marry

The parties to an impending marriage are required by law to publicise the intended marriage so that any legal obstacles may present themselves before the marriage is solemnised. ${ }^{225}$ Parties who elect to marry according to the rites of the Church of England are given a choice as to which of the preliminaries they wish to observe, the most popular one being the posting of banns in the parishes where they reside. ${ }^{226}$ Where the couples wish to avoid this publicity, they are allowed marry by licence, which requires them to declare their freedom to conclude the marriage to the relevant church authorities. ${ }^{227}$ In addition to the two options mentioned above, parties can also marry by special licence, which is obtained from the Archbishop of

222 Padolecchia v Padolecchia [1967] 3 All ER 863; Maples v Maples [1987] 3 All ER 188.

223 Probert Family and Succession Law in England and Wales 76.

224 Burton Family Law 13.

225 Probert Family and Succession Law in England and Wales 76.

226 S 5 of the Marriage Act 1949.

227 Probert Family and Succession Law in England and Wales 77. 
Canterbury and which allows the parties to be married at any time or place. ${ }^{228}$

In addition to the above preliminaries, a marriage in the Church of England may also be preceded by civil preliminaries. ${ }^{229}$ The same preliminaries apply to civil weddings and to marriages celebrated according to non-Anglican rites. In terms of the civil preliminaries, the parties are required to give notice of their intention to marry in person to their local superintendent registrar. ${ }^{230}$ The details of the parties will be displayed at the superintendent's office for a period of 15 days and, provided no objections are lodged against the impending marriage, the superintendent will issue a certificate authorising the marriage to go ahead. ${ }^{231}$

(ii) Celebration

(1) The place of celebration

A marriage solemnised according to the rites of the Church of England must be conducted in the Anglican Church, unless the parties have opted to be married by special licence. ${ }^{232}$ In order for members of other religious denominations to conclude a marriage according to the rites of their religion at their local place of worship, that place of worship must be registered and licensed for marriages, and the celebrant must be authorised to conduct marriage ceremonies. ${ }^{233}$ Where the local place of worship does not comply with these requirements, ${ }^{234}$ the parties will have to conclude a civil ceremony of marriage, either in addition to, or instead of the religious marriage, for their marriage to be legally recognised. ${ }^{235}$

A civil ceremony can be concluded at any place that has the approval of the local authority. ${ }^{236}$ Persons who are terminally ill are allowed to conclude a marriage at their home or in a hospital, while those persons who are housebound, or who have been detained, may enter into a marriage at the place where they are confined. ${ }^{237}$

The celebrant (marriage officer)

An Anglican marriage must be solemnised by a clergyman of the Church of England. ${ }^{238}$ The marriage is deemed to be void if the parties knowingly and

\footnotetext{
228 Cretney et al Principles of Family Law 21.

229 S 17 of the Marriage Act 1949.

230 S 27 of the Marriage Act 1949; Cretney et al Principles of Family Law 16.

231 S 27 of the Marriage Act 1949; Cretney et al Principles of Family Law 17.

232 Marriage Act 1949, s 12 (marriage with banns); s 15 (marriage by common licence); s 17 (marriage under superintendent registrar's certificate).

233 Ibid.

234 There are many mosques and temples that are not registered and licensed places of worship.

235 Probert Family Law and Succession in England and Wales 78.

236 Marriage Act 1994.

237 S 27 of the Marriage Act 1949 as amended by the Marriage Act 1983.

238 S 25 of the Marriage Act 1949.
} 
wilfully consent to the solemnisation of their marriage by a person who is not under Holy orders. ${ }^{239}$ Similarly, a civil marriage is void if the parties knowingly and wilfully consent to the solemnisation of their marriage by a person who is not a superintendent registrar. ${ }^{240}$ In respect of other religious marriages celebrated in registered buildings, these must be solemnised by either an authorised person ${ }^{241}$ or a superintendent registrar. ${ }^{242}$

The content of the ceremony

Where the parties conclude their marriage according to the rites of the Church of England, the relevant religious authorities determine the content of the marriage ceremony. ${ }^{243}$ In the case of civil marriages, the parties themselves determine the content of the ceremony. ${ }^{244}$ Parties to civil marriages and religious marriages celebrated in registered buildings must make a declaration that they are free to marry each other and that they take one another as husband and wife. ${ }^{245}$

\section{(iii) Registration of marriages and civil partnerships}

All marriages and civil partnerships that are solemnised in England and Wales must be registered. ${ }^{246}$ Non-registration of the marriage does not affect the validity of the marriage. ${ }^{247}$ The responsibility for the registration of the marriage is borne by the person conducting the marriage ceremony, ${ }^{248}$ or the person who is appointed for the purpose of registering the marriage. ${ }^{249}$

\section{Comparison}

A notable similarity in Islamic, South African and English law is that a marriage is concluded by an offer and an acceptance of the offer of marriage. As far as the requirements for a valid marriage are concerned, while all three legal systems share common requirements, there are marked differences as to what these requirements entail. These differences are discussed with reference to the requirements for a valid marriage - namely, legal capacity, consensus, lawfulness and formalities.

Although all three legal systems require that the prospective bride and groom possess the necessary capacity to enter into a marriage, the difference in respect of this requirement lies in the fact that, while South

239 Ibid.

$240 \mathrm{~S} 49(\mathrm{~g})$ of the Marriage Act 1949.

$241 \mathrm{~S} 43$ of the Marriage Act 1949.

242 S 49( $f)$ of the Marriage Act 1949.

243 Probert Family Law and Succession in England and Wales 79.

244 Ibid.

245 S 44(3) of the Marriage Act 1949; see Cretney et al Principles of Family Law 27.

246 S 65 of the Marriage Act.

247 Probert Family and Succession Law in England and Wales 80.

248 S 47 of the Marriage Act 1949.

249 The secretary of the synagogue will register the marriage where a marriage according to the Jewish faith is concluded, and the registering officer of the Society of Friends will register the marriage in the case of Quakers. 
African and English legal systems prescribe specific categories of ages for marriage, Islamic law requires the parties to reach the age of puberty, without stipulating a specific age.

Similarly, all three legal systems require the parties to the marriage to be of sound mind when entering into the marriage. Islamic law makes provision for a person with mental illness to conclude a marriage, provided that the mental illness is disclosed to the other party and also makes provision for a woman with mental illness to conclude a valid marriage where a physician leads evidence that the marriage would be a cure for the mental illness. In contrast, both South African and English law regard the marriage of a person with mental illness as valid only if the person experiences a lucidum intervallum at the time the marriage is concluded. Bar this exception, the marriage of a person suffering from mental illness is void. Therefore, if a person is unable to consent to his or her marriage as a result of mental illness, the parent or guardian is also prohibited from granting consent to the marriage.

While consent is a common requirement in all three legal systems, Islamic law requires that, in addition to the consent of the prospective bride, her guardian also has to give his consent in order for the marriage to be valid. This is the position irrespective of the age of the woman entering into the marriage. It is only where the prospective groom is a minor that the consent of his guardian is required. This is in stark contrast to South African and English law where only the consent of each party is required, unless the party is a minor. Cognisance must, however, be taken of the fact that the age of minority differs in the South African and English legal systems.

Another significant difference between Islamic law and South African and English law is that, in the latter two legal systems, both prospective spouses must expressly consent to the impending marriage while Islamic law makes provision for tacit consent.

Insofar as the requirement of lawfulness is concerned, the prohibitions with regard to consanguinity and affinity are very similar in all three legal systems. Although the institution of adoption is not recognised in Islamic law, a prohibited degree of relationship is created where fosterage has occurred.

A profound difference between Islamic law on the one hand, and South African and English law on the other, relates to the choice of a marriage partner. Islamic law strictly prohibits the marriage between a Muslim woman and a non-Muslim man. In contrast, South African and English family law places no legal prohibition in respect of a marriage between parties who have different religious beliefs.

Islamic law makes provision for polygynous marriages, as it allows the man to have a maximum of four wives at a time. A man who already has four wives, is prohibited from entering into a marriage with a fifth wife, unless he divorces one of his other wives. A married Muslim woman is, however, prohibited from entering into another marriage without the previous marriage being terminated either by death or divorce. In addition to this, the woman has to observe the compulsory waiting period before she can enter into a valid marriage. These prohibitions do not exist in South African or English law. Civil marriages and unions concluded in terms of South African or 
English law are strictly monogamous, and a person who concludes a civil marriage or union with more than one spouse is guilty of bigamy.

Islamic law, unlike South African and English law, does not make provision for same-sex marriages or unions.

In respect of the witnesses, Islam draws a distinction between circumstances where the witnesses are male or female. If there are two males present to witness the conclusion of the marriage, this will suffice. The presence of one male witness must be accompanied by two female witnesses for the marriage to be valid. South African and English law draws no such distinction.

Although the payment of dowry to the prospective bride is not an essential requirement for the validity of the marriage, it is still regarded as indispensable to a marriage concluded in terms of Muslim rites. In South African and English law, where a civil marriage is concluded, there is no payment of dowry to the prospective bride.

Both Islamic law and English law require the observance of formalities in respect of the publication of the marriage. English law, however, requires the publication of the intended marriage and further draws a distinction between a marriage concluded in terms of the rites of the Church of England and one concluded by special licence; the former requires publication, while the latter does not. Islamic law requires publication of the marriage only after it has been concluded so as to differentiate the marriage from mere fornication. South African law contains no requirements in respect of the publication of a marriage, either before or after the marriage is concluded - except that the marriage must be solemnised in a church or other building used for religious service, public office or private dwelling with open doors so as to avoid clandestine marriages. ${ }^{250}$

As far as the place for the conclusion of the marriage is concerned, Islamic law is not prescriptive in this regard and a marriage can be solemnised at any place, although it is preferable that it be concluded in a mosque. In terms of South African law, the Marriage Act provides that a marriage can be solemnised at any public or private dwelling. English law requires a marriage to be solemnised in the Anglican Church where the marriage is concluded according to the rites of the English Church unless the parties have elected to be married by special licence. If the parties wish to conclude a civil marriage, the place where the marriage is solemnised must have the approval of the local authority.

A marriage in terms of Islamic rites can be concluded by a learned religious scholar, or the father of the bride can elect to conclude the marriage. In contrast, both South African law and English law require that a designated marriage officer solemnise the marriage.

Both South African and English law require the marriage to be registered. However, non-registration of the marriage with the local authorities does not affect the validity of the marriage. A marriage in terms of Islamic rites is not registered. The person performing the marriage will issue the parties with a

250 S 29(2) of the Marriage Act 25 of 1961. 
marriage certificate but no relevant official authority exists for the registration of the marriage.

\section{MARITAL RIGHTS AND DUTIES}

The legal consequences of a marriage are far reaching for the spouses in respect of their person and their property. As far as the legal consequences of marriage are concerned, a distinction can be drawn between the personal and proprietary consequences of a marriage.

\section{Personal consequences}

\section{Islamic law}

\section{The duties of the husband}

The duties of the husband include the payment of dower, maintenance, the provision of suitable accommodation, treating the wife with kindness and displaying equality where he has entered into a polygamous marriage.

\section{(i) Dower}

The first and foremost duty of the husband is the payment of dower to the wife. ${ }^{251}$ The payment of a dower ( $\left.m a h r\right)$ is an indispensable component of an Islamic marriage contract. ${ }^{252} \mathrm{Mahr}$ is anything of value and it incorporates either a sum of money or property that becomes payable by the husband to the wife after the prospective spouses have agreed to conclude the marriage. ${ }^{253}$ The payment of dower at the conclusion of the marriage is obligatory by the husband. ${ }^{254}$

The validity of the marriage will not be affected if the amount of dower has not been specified or paid at the time of marriage. ${ }^{255}$ The husband, however, is not discharged from his duty to make payment of the dower and he is obligated to make payment of the dower at the time that the marriage is consummated or any time thereafter. ${ }^{256}$ The dower becomes the sole property of the bride. 257 The dower remains the property of the wife, even where the marriage is dissolved through divorce. ${ }^{258}$ The wife becomes the owner of the dower as soon as the marriage is solemnised. ${ }^{259}$

\footnotetext{
Siddiqi The Family Laws of Islam 106.

Siddiqi The Family Laws of Islam 107.

53 Nasir The Status of Women Under Islamic Law 87; Doi Shari'ah The Islamic Law 158-166.

Siddiqi The Family Laws of Islam 79; Quran ch 4, verse 4 and 24.

Siddiqi The Family Laws of Islam 80.

Ibid.

Doi Shari'ah The Islamic Law 158; The Holy Quran ch 4, verse 4.

58 Doi Shari'ah The Islamic Law 158. The only exception to this principle is when the marriage is dissolved by means of a khula - that is, where the marriage is dissolved at the request of the wife in consideration of the return of all or a portion of the dower paid to her.

259 Doi Shari'ah The Islamic Law 159.
} 
The sum or value of the dower is not prescribed by law - rather it may be decided by the parties, or it may be determined via the operation of Islamic law, with due regard to the social status of the parties. ${ }^{260}$ However, the dower must be something of value, even if it is worth a small amount. ${ }^{261}$

The dower does not constitute a bride price with which the husband purchases the wife upon the payment of dower. ${ }^{262}$ The purpose thereof is to emphasise the prestige and importance of the contract of marriage. ${ }^{263}$ Furthermore, the dower is regarded as a token of the husband's love and affection that he offers to the wife when they enter into the contract of marriage. 264

The payment of the dower can be effected in one of three ways: the transfer of the dower to the wife may be made immediately upon the conclusion of the marriage; the payment of the dower may be deferred to a later date; or the payment of a portion of the dower may be made at the conclusion of the marriage, the balance to be paid if and when the marriage is dissolved by divorce or death of the husband. ${ }^{265}$ The manner in which payment of the dower is effected depends on the terms of the marriage contract between husband and wife; in the absence of a marriage contract, it would depend on the custom of the country in which they are living. ${ }^{266}$

\section{(ii) Maintenance (Nafaqah)}

The second duty of the husband is to provide maintenance to his wife as the wife has the right to be provided with food, clothing and housing at the expense of the husband, on a scale suitable to his means. ${ }^{267}$ With regard to the amount of maintenance, the position and social status of both spouses must be taken into account. 268 Where both spouses are wealthy, the maintenance provided to the wife should be of that standard. ${ }^{269}$ The same applies where both spouses are not financially well off. ${ }^{270}$ If a wife is wealthy and the husband is not, the wife in this instance would be entitled to reasonable maintenance. ${ }^{271}$

Maintenance (nafaqah) is primarily the husband's duty, regardless of the private means of the wife. ${ }^{272}$ The wife is under no obligation to contribute financially towards the running of the household, and where she does, she may claim such amounts from her husband. ${ }^{273}$ Furthermore, if the wife

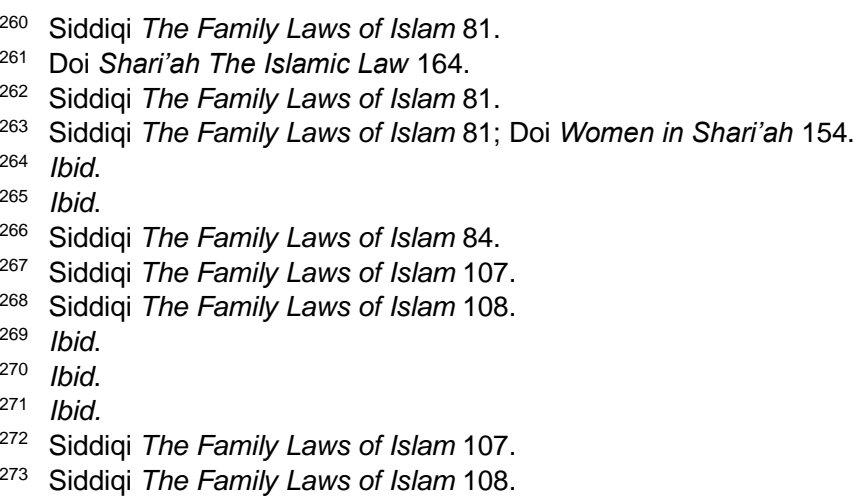


cannot perform her household duties due to illness, or where the wife is wealthy and she refuses to do any domestic work as she considers it to be beneath her dignity, it is the duty of the husband to provide her with cooked food, for example. ${ }^{274}$

Where the marriage is dissolved, the husband is under an obligation to provide accommodation and maintain the wife during the three-month waiting period (iddah). ${ }^{275}$ Once the three-month waiting period has elapsed, the husband is not obliged to pay maintenance to his former wife. ${ }^{276}$ According to the Shafi'i madhhab, where the husband fails to provide nafaqah to his wife, this constitutes a debt that the husband is obliged to pay to the wife. 277 In other words, the wife is entitled to claim for arrear nafaqah during and after the termination of the marriage. ${ }^{278}$

\section{(iii) Residence}

The general rule is that the husband is under an obligation to provide his wife with suitable accommodation or housing according to his means as long as the marriage subsists. ${ }^{279}$ This is also the position where the marriage is terminated by divorce, as the divorced wife is entitled to remain in the marital home during her period of $i d d a h .{ }^{280}$ For as long as the marriage subsists, the husband bears the sole responsibility of providing accommodation and maintenance for his wife. ${ }^{281}$ Where the husband has leased property to provide accommodation for his wife, he bears the sole responsibility to pay the rental of the property. ${ }^{282}$

\section{(iv) Treatment of wives}

The Prophet Muhammad (PBUH) in his last sermon repeatedly admonished men to treat their wives with kindness and respect, and in fact laid great emphasis upon kind and good treatment towards the wife. ${ }^{283}$ The husband is, therefore, obliged to treat his wife with kindness, love and respect in order for peace and happiness to prevail within the marital home.

\section{(v) Equality between wives}

Where a husband is practising polygyny, it is incumbent upon him to treat all his wives equally, as all wives are deemed to be equal in status and should enjoy equal rights. ${ }^{284}$ The husband is therefore required to treat all his wives

274 Siddiqi The Family Laws of Islam 108-109.

275 Ayoub Fiqh of Muslim Family 347.

276 The rule applies unless the wife is pregnant or is breastfeeding, in which case the husband is obliged to maintain the wife until the birth of the child or the completion of breastfeeding.

277 Esposito and DeLong-Bas Women in Muslim Family Law (2001) 115.

278 Ibid.

279 Siddiqi The Family Laws of Islam 109.

280 Siddiqi The Family Laws of Islam 109.

281 Ibid.

282 Ba'-kathah Tuh-fatul Ikhwaan 157.

283 Siddiqi The Family Laws of Islam 109.

284 Siddiqi The Family Laws of Islam 115. 
equally with regard to the provision of maintenance as well as the time spent with each wife. ${ }^{285}$

\section{The duties of the wife}

Islam allows a wife certain rights that place duties upon her husband, but similarly the wife owes certain duties towards her husband.

\section{(i) Guarding the husband's rights}

Faithfulness and chastity are regarded as the first duties of the wife. ${ }^{286}$ In the husband's absence, it is the duty of the wife to guard his possessions, which include his offspring, property and honour. ${ }^{287}$

\section{(ii) Management of household affairs}

The second duty of the wife includes the supervision of the family home, as well as the improvement and protection of family relationships. ${ }^{288}$ The primary duties of the wife can therefore be listed as the management of the household and the rearing of the children. ${ }^{289}$ These duties do not detract from the fact that a woman, more specifically a wife, has the right to engage in employment, to seek education and even to defend her country in the same manner as a man, if she is required to do so. ${ }^{290}$

The wife is under no obligation to provide personal services, such as cooking meals and cleaning the marital home. ${ }^{291}$ Where she does undertake these duties, it is regarded as a favour that she does for her husband. According to the sunnah practices of the Prophet Muhammad (PBUH), both husband and wife should assist each other with regard to duties in the marital home. ${ }^{292}$

\section{(iii) Headship of the family}

Although Islam advocates the idea that the marital home is viewed as a kingdom ruled by both husband and wife, Islam is patriarchal in nature and the husband is regarded as the head of the family, having the decisive say in all matters. ${ }^{293}$ The wife is, therefore, required to obey her husband in matters relating to the well-being and happiness of the family unit, as well as in matters relating to the upbringing of their children. ${ }^{294} \mathrm{~A}$ wife may, however, refuse to obey her husband if he requires her to do that which is contrary to

\footnotetext{
285 Ibid.

286 Siddiqi The Family Laws of Islam 118.

Ibid.

Nasir The Status of Women Under Islamic Law 81.

Alkhuli The Light of Islam 78.

Ibid.

Siddiqi The Family Laws of Islam 119.

Siddiqi The Family Laws of Islam 119.

Alkhuli The Light of Islam 77.

94 Siddiqi The Family Laws of Islam 120.
} 
the teachings and rulings of Islam. ${ }^{295}$ If the husband, for example, forbids the wife to do the compulsory fasting during the month of Ramadan, the wife is not required to obey him. ${ }^{296}$

\section{(iv) Family name}

Upon the solemnisation of a marriage, a Muslim woman does not lose any of the rights she had prior to the marriage; as a married woman, she retains her individuality and her name. ${ }^{297}$ Although in practice, most women accept their husbands' surnames, Islam permits women to retain their maiden surnames. ${ }^{298}$ In fact, the opinion among the majority of Islamic jurists is that the woman is required by Islamic law to retain her surname and not adopt that of her husband. ${ }^{299}$

\section{South African law}

\section{Maintenance}

One of the invariable consequences of a civil marriage is the reciprocal duty of support that arises between spouses as soon as the marriage is solemnised. ${ }^{300}$ The reciprocal duty of support between spouses applies to all marriages concluded in terms of civil law, ${ }^{301}$ regardless of which matrimonial property regime the parties have chosen to regulate their marriage. ${ }^{302}$ Furthermore, the duty of support subsists throughout the marriage and can under certain circumstances be extended, even after the marriage has been terminated, either through divorce or by the death of one of the parties to the marriage. ${ }^{303}$

The reciprocal duty of support arises when the spouse who claims maintenance is in need of it, and the spouse from whom maintenance is claimed is in a financial position to provide the maintenance claimed. ${ }^{304}$

The reciprocal duty of support means that both husband and wife have a duty to support each other on a pro rata basis according to their respective means. ${ }^{305}$ In terms of the common law, spouses can fulfil their duty of support in one of two ways - either by providing the necessary finances to purchase what the other requires, or alternatively by providing certain kinds of service, such as doing the housework in the marital home or looking after

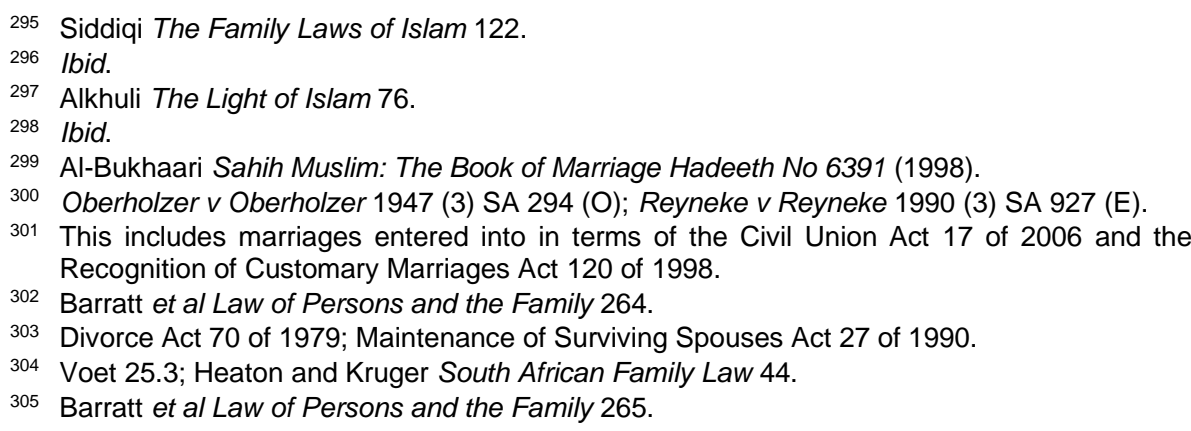


the children born of the marriage. ${ }^{306}$ The provision of accommodation, food, clothing, medical expenses and litigation costs are examples of items that typically fall within the duty of support. The duty of support is not limited to the bare necessities of life, but is rather determined by the spouses' standard of living, their financial means or income and the cost of living. ${ }^{307}$ Therefore, overseas holidays, weekly visits to the hairdresser and expensive cars, for example, are items that may well fall within the duty of support if the person from whom support is being claimed is a wealthy person. ${ }^{308}$

Where the duty of support is not being fulfilled, the spouse claiming maintenance can enforce the duty of support by instituting a maintenance claim in either the High Court or a maintenance court. ${ }^{309}$ In terms of section 3 of the Maintenance Act, ${ }^{310}$ maintenance courts are empowered to grant both maintenance orders and civil and criminal sanctions where a party fails to comply with the maintenance order.

Both spouses in a civil marriage have the power to bind each other in contract for the things and services that are necessary for the running of the joint household, irrespective of the matrimonial property system regulating the marriage, and irrespective of which spouse buys the household necessaries. ${ }^{311}$ The capacity to conclude binding contracts for the purchase of household necessities is an automatic consequence of marriage that cannot be excluded by an antenuptial contract. ${ }^{312}$ In modern times, spouses share the duty to purchase and pay for household necessities on a pro rata basis according to their means. ${ }^{313}$ The spouses will only have the power to bind each other contractually for the purchase of household necessities if: they have entered into a valid civil marriage; a joint household exists at the time the purchase is made; 314 and the item purchased must be a household necessity. ${ }^{315}$

\section{Residence}

One of the most important invariable consequences of a civil marriage is the creation of the consortium omnis vitae ${ }^{316}$ that includes the duty and the right to live together in their marital home. ${ }^{317}$ The general rule is that neither spouse can evict the other from the marital home, irrespective of the matrimonial property regime, and irrespective of which one owns the marital home. ${ }^{318}$ The right to live in the marital home includes the right to possession

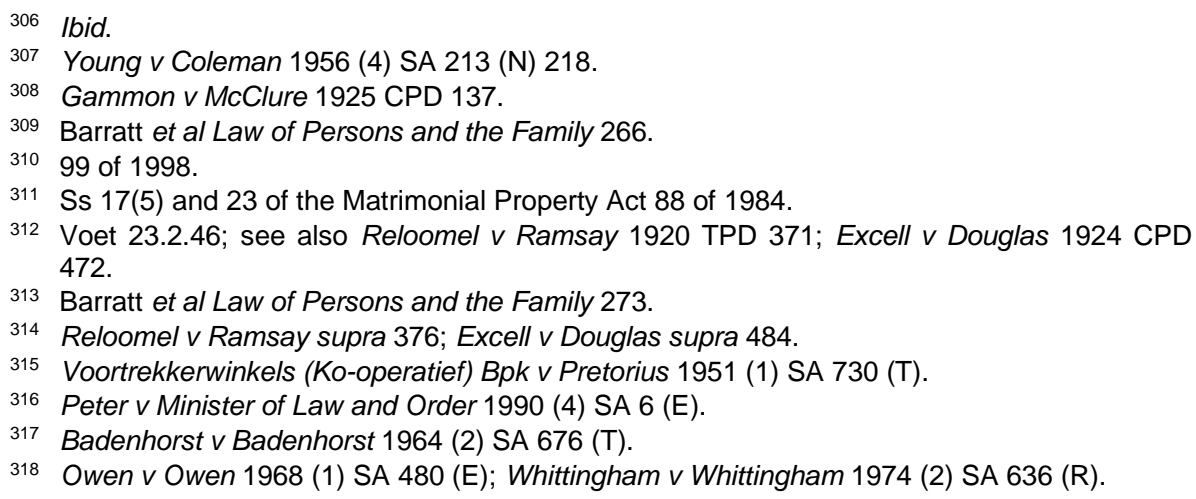


and use of the household furniture and other effects, regardless of which one of the spouses owns the items. ${ }^{319}$ In the event that one of the spouses threatens the other spouse in respect of the use and enjoyment of the marital home or the household effects, the threatened spouse can apply for an interdict to prevent this. ${ }^{320}$ Where one spouse has already been evicted from the marital home, or has been dispossessed of household goods, the aggrieved spouse can apply, by means of the mandament van spolie, to regain possession of the marital home or the household effects. ${ }^{321}$ The mandament van spolie can also be used to regain possession of household effects, as the one spouse cannot dispose of the household furnishings and effects and leave the other spouse with only the "empty shell of the matrimonial home". ${ }^{322}$ The exception to the general rule that a spouse cannot be evicted from the marital home arises in domestic violence matters where a spouse applies for a protection order in terms of the Domestic Violence Act. ${ }^{323}$ If a protection order is granted, the guilty spouse may be prevented from entering the marital home or living in it.

\section{Treatment of spouses}

Closely related to the creation and protection of the consortium omnis vitae that arises automatically when a civil marriage is concluded is the treatment of spouses. Although the term consortium omnis vitae does not lend itself to precise legal definition, it includes both intangibles (such as love, loyalty and care) and the more material needs of life (for example, physical care and financial support). ${ }^{324}$ However, although spouses have consortium duties towards each other, these duties cannot be enforced in a court of law. ${ }^{325}$ Where one or both spouses fail in performing the interpersonal aspects of the consortium, the aggrieved spouse can institute an action for divorce on the basis that the marriage has broken down irretrievably.

\section{Family name}

In modern South African society, most married women still assume their husband's surname although it is not necessary for them to do so. ${ }^{326}$ In terms of section 26(1) of the Births and Deaths Registration Act, 327 a person is not allowed to change his or her surname unless the required authorisation has been obtained from the Director-General of Home Affairs. However, section 26(1) does not apply to women who marry or who have been married because a wife does not need official permission to assume her husband's surname after the solemnisation of her marriage, ${ }^{328}$ or after

319 Whittingham $v$ Whittingham supra; Buck v Buck 1974 (1) SA 609 (R).

320 Buck v Buck supra; Du Plessis v Du Plessis 1976 (1) SA 284 (W).

321 Manga v Manga 1992 (4) SA 502 (ZSC); Du Randt v Du Randt 1995 (1) SA 401 (O).

322 Whittingham $v$ Whittingham supra.

323116 of 1998.

324 Peter $v$ Minister of Law and Order supra 9.

325 Boon v Boon (1898) 8 CTR 397.

326 Heaton and Kruger South African Family Law 59.

32751 of 1992.

$328 \mathrm{~S} 26(1)(a)$ of 51 of 1992. 
having assumed his surname, to resume a surname she bore at any prior time, ${ }^{329}$ or to add her married surname to any surname she bore at any prior time. ${ }^{330} \mathrm{~A}$ divorced or widowed woman may assume a surname she bore at any previous time. ${ }^{331}$ Where a man wishes to assume his wife's surname, or add it to his own surname, he is required to apply to the Director-General of Home Affairs for permission. 332 In addition to the differential treatment of men and women as cited above, there is also differential treatment between men married in terms of the Marriage Act and partners in a civil union, as section 26(1) of the Births and Deaths Registration Act allows spouses to a civil union to change their surnames without obtaining official consent from the Director-General of Home Affairs to do so. It is submitted that there is no constitutionally acceptable justification for the differentiation.

\section{Headship of the family}

In terms of the common law, the husband was head of the family and had the decisive say in all matters concerning the common life of the spouses for example, where and in what style they live. ${ }^{333}$ The husband's commonlaw status as head of the family was expressly incorporated into section 13 of the Matrimonial Property Act, ${ }^{334}$ providing that, although the husband's marital power over the wife has been abolished, this would not affect the husband's position as the head of the family. The legislature attempted to remove the husband's headship with the enactment of section 30 of the General Law Fourth Amendment Act, ${ }^{335}$ which repealed section 13 of the Matrimonial Property Act. Sinclair submits that, although section 13 was repealed, the common-law rule that recognises the husband as the head of the family remains unchanged. ${ }^{336}$ However, in modern South African society, the husband's common-law headship of the family has very little practical significance and no longer has any substantial content, as the major practical aspects of the husband's headship have been abolished through the enactment of several other statutes. ${ }^{337}$ The continued existence of the common-law rule in respect of the husband's headship is unconstitutional as it is discriminatory on the ground of gender, which is a violation of sections 9 and 10 of the Constitution. 338

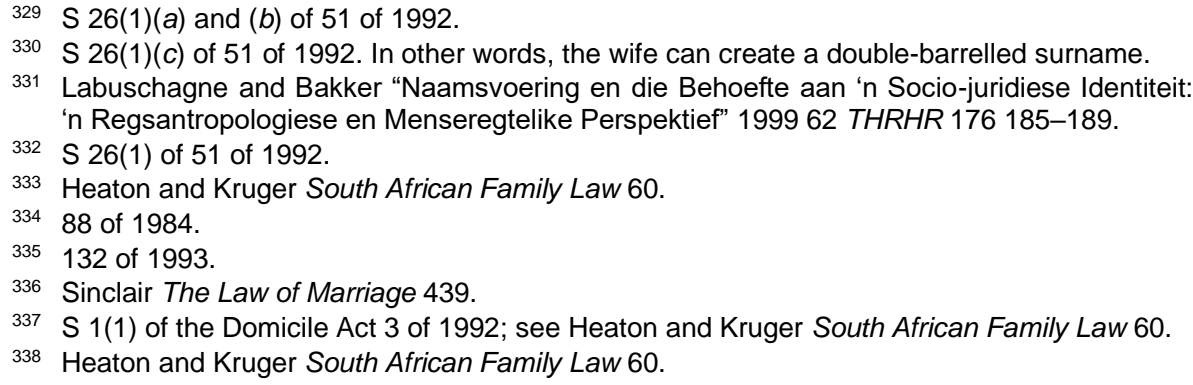




\section{The law of England and Wales}

\section{Maintenance}

In terms of the common law, the husband had a duty to support his wife according to his means. ${ }^{339}$ The Equality Act 2010 has abolished the sexspecific rule. At present, the duty of support is regulated by statute, ${ }^{340}$ which provides that a reciprocal duty of support exists between the spouses at the conclusion of the marriage. Where one spouse fails to discharge the duty of support, the aggrieved spouse can lodge an application to court for an order for financial provision. ${ }^{341}$ The Domestic Proceedings and Magistrates' Court Act 1978 authorises a magistrates' court to grant periodical or lump-sum financial orders where one spouse has failed to provide reasonable maintenance for the other spouse. ${ }^{342}$ Where one spouse has not discharged his or her duty to provide reasonable maintenance to the other spouse, an application for maintenance can also be lodged in the county court or the High Court. ${ }^{343}$

Furthermore, there is no legislation regulating the specific obligations of the spouses during the subsistence of the marriage. ${ }^{344}$ There is no requirement that the spouses share the expenses of the household equally, or even that each spouse is required to make a fair contribution to the expenses of the household. ${ }^{345}$ The only specific provision relating to the expenses of the household is in respect of the ownership of any surplus saved from a housekeeping allowance. ${ }^{346}$ In terms of the common-law rules, ownership of the surplus belonged to the spouse who provided the allowance. ${ }^{347}$ The common-law rule was amended by the Married Women's Property Act 1964, which provided that a wife is entitled to half of any savings she made out of a housekeeping allowance. The Equality Act 2010 subsequently changed this by providing that any surplus savings are to be shared between the spouses irrespective of who provided the housekeeping allowance. 348

\section{Residence}

There is no statutory code or provision regulating the ownership or disposition of the matrimonial home. ${ }^{349}$ While each spouse acquires the right to occupy the matrimonial home, the ownership thereof is governed, largely

\footnotetext{
339 Probert Family and Succession Law in England and Wales 85.

340 Domestic Proceedings and Magistrates' Courts Act 1978; Matrimonial Causes Act 1973.

341 S 27 of the Matrimonial Causes Act 1973

$342 \mathrm{~S} 1$ of the Domestic Proceedings and Magistrates' Courts Act 1978.

343 S 27 of the Matrimonial Causes Act 1973.

344 Ibid.

345 Ibid.

346 Ibid.

347 Ibid.

348 S 200 of the Equality Act 2010.

349 Probert Family and Succession Law in England and Wales 177.
} 
by the law of trusts. ${ }^{350} \mathrm{~A}$ spouse who has sole legal and beneficial ownership of the matrimonial home is at liberty to dispose of the matrimonial home as he or she deems fit, without consulting the other spouse. ${ }^{351}$ There are certain steps that an aggrieved spouse can take to prevent the other spouse from disposing of the marital home without obtaining consent, but the protection afforded in this instance is not automatic and simply serves to delay the sale of the matrimonial home. ${ }^{352}$

Where the parties are joint beneficial owners of the matrimonial home, each spouse has the right of occupation. ${ }^{353}$ Where one spouse is the sole legal owner, but the other spouse has a beneficial interest in the matrimonial home, the former spouse is obligated to consult the latter in respect of any dealings with the matrimonial home. ${ }^{354}$ Where the spouse who is the sole legal owner sells the property, the proceeds thereof are divided according to the spouses' respective beneficial interests. ${ }^{355}$

The right to occupy the marital home as a consequence of statutory "home rights" means that the exclusion of one spouse from the marital home by the other spouse can take place only where this is court-sanctioned. ${ }^{356}$ Section 33(3) of the Family Law Act 1996 also authorises a court to make an order granting a spouse who is not currently occupying the marital home, the right of entry and occupation even where the other spouse is opposed to it. The general rule in respect of the termination of home rights is that they are terminated only at the dissolution of the marriage, whether by death, divorce or annulment.

\section{Treatment of spouses}

Traditionally, upon the conclusion of a marriage, a consortium is created between the spouses that includes, among others, the practical aspects of living together in marriage, the right to sexual intercourse, the right to occupy the matrimonial home and respect for marital confidences. ${ }^{357}$ Therefore, once a marriage is concluded, the spouses are required to live together as husband and wife as this forms part of the legal concept of consortium. ${ }^{358}$ The importance of the spouses living together can be inferred from the fact that a spouse may apply for a divorce on the ground of desertion if the other spouse refuses to live with him or her. ${ }^{359}$ Despite the spouses having the right to consortium, it is not a right that the law allows the individual to enforce, either through self-help $p^{360}$ or an order of the court. ${ }^{361}$

\footnotetext{
350 Ibid.

351 Probert Family and Succession Law in England and Wales 177.

352 Probert Family and Succession Law in England and Wales 178.

353 Probert Family and Succession Law in England and Wales 181.

354 S 11 of the Trusts of Land and Appointment of Trustees Act 1996.

355 Probert Family and Succession Law in England and Wales 182.

356 S 30 of the Family Law Act 1996.

357 Burton Family Law 36.

358 Probert Family and Succession Law in England and Wales 85

359 Ibid.

$360 R$ v Jackson [1981] 1 Q.B. 671.

361 Best $v$ Samuel Fox \& Co Ltd [195] A.C. 716731.
} 


\section{Family name}

Although there is no legal obligation for a woman to change her name, and while either spouse can adopt the other's surname on the conclusion of a marriage, it is generally the wife who adopts the surname of her husband. ${ }^{362}$ It has, however, become increasingly common for spouses to retain their own surname or to combine their surnames. ${ }^{363}$ Where a marriage is terminated either by death or divorce, a woman is under no obligation to resume her maiden name where she had adopted the surname of her husband. ${ }^{364}$ An adult, male or female, is allowed in terms of the law to adopt whatever surname or forename he or she chooses, as long as there is no intent to deceive. ${ }^{365}$ Despite no formal procedure required to effect a name change, state officials will require documentary proof before effecting a name change. ${ }^{366}$

\section{Comparison}

As far as similarities between the three legal systems are concerned, marriage in Islamic, South African and English law creates a consortium omnis vitae between the spouses that requires husband and wife to remain faithful to each other and to treat each other with kindness, to live together and to support each other.

The differences between the three legal systems relate to the payment of dowry, maintenance, residence, headship of the husband and family name.

South African law and English law do not require a woman to assume the surname of her husband when concluding a marriage.

Although it is not a legal requirement and does not affect the validity of the marriage, Islamic law places an obligation upon the husband to pay a dowry to his wife. There exists no such obligation when the parties enter into a marriage in terms of South African or English law.

Unlike the position in Islamic law, where the husband bears the sole duty of support, the position in South African and English law as far as spousal maintenance is concerned, is that there is a reciprocal duty of support between spouses. Furthermore, in terms of South African and English law, this reciprocal duty of support exists throughout the marriage, and can even be extended in certain circumstances upon dissolution of the marriage. The prevailing position in Islamic law is that the husband bears the sole responsibility for support during the subsistence of the marriage, and where the marriage is dissolved through divorce, the husband is only obligated to maintain the woman for a period of three months after the divorce has taken place.

\footnotetext{
Probert Family and Succession Law in England and Wales 55

63 Probert Family and Succession Law in England and Wales 89.

364 Probert Family and Succession Law in England and Wales 55.

365 Ibid.

366 Ibid.
} 
Islamic law delegates the management of the household, and the purchases relating to the household, to the wife. The husband is, however, required to provide the financial means to his wife in order for her to fulfil this duty. South African law grants both spouses the authority to bind each other for the purchase of household necessities and where the parties are married in community of property, section 15 of the Matrimonial Property $\mathrm{Act}^{367}$ grants both spouses equal powers of administration in respect of the joint estate. In terms of English law, there is no requirement that the spouses share the expenses of the household equally, or even that each spouse is required to make a fair contribution to the expenses of the household. This position differs markedly from the position in both Islamic law as well as South African law.

As far as the marital home is concerned, in Islamic law, it is the sole duty of the husband to provide the wife with suitable accommodation according to his means. The wife is entitled to remain in the marital home during the subsistence of the marriage as well as during her iddah period if the marriage is dissolved by divorce. Once the iddah period expires, the husband is allowed to evict the wife from the marital home. In terms of South African and English law, both parties have the right to occupy the marital home during the subsistence of the marriage and neither spouse can evict the other from the marital home.

Islamic law requires the wife to obey the husband in respect of all matters unless it is contrary to the principles of Islam. In terms of South African law, there is no similar duty upon the wife where the parties are civilly married in terms of the Marriage Act or Civil Union Act. However, Islamic law and South African common law are to a certain extent patriarchal in nature as the husband is regarded as the head of the family, having the decisive say in matters relating to the family. The common-law rule, however, is subject to constitutional scrutiny as it discriminates on the basis of sex or gender in terms of section 9 and 10 of the Constitution. ${ }^{368}$

\section{Property rights}

\section{Islamic law}

\section{Property rights}

Community of property is not recognised under Islamic law. Spouses to an Islamic marriage maintain separate estates and each spouse retains sole ownership and control of his or her property, whether movable or immovable, and whether acquired before or after the marriage. ${ }^{369}$ According to authentic narrations from Islamic jurists, 370 a person is only allowed to receive benefits and wealth that is earned through lawful means; thus if the parties were married in terms of a shared matrimonial property system, for

\footnotetext{
88 of 1984.

68 Heaton and Kruger South African Family Law 62.

369 Rautenbach and Bekker Introduction to Legal Pluralism 368.

370 Ibn Katheer Tafseer al-Quran al-Adheem (2003) Vol 193.
} 
example, one spouse would become entitled to receive benefits to which he or she was not Islamically entitled.

The complete separation of assets is often very prejudicial to a spouse who is not the primary breadwinner, as a spouse who has very little income or no income at all is unable to amass his or her own estate. If an asset is registered only in the husband's name, for example, the wife has no legal claim to the asset. This could prove very disadvantageous to her if the marriage is dissolved by divorce and she has no assets to her name.

Under Islamic law, the woman enjoys an absolute right to earn, acquire and inherit property. ${ }^{371}$ She also possesses the right of ownership over her goods and wealth independent of any male. ${ }^{372}$ She is entitled to instruct any person of her choice to deal with her property without consulting her husband, and she has the right to dispose of her assets as she sees fit. ${ }^{373}$ Muslim jurists are unanimous ${ }^{374}$ that, where the wife is of sound mind, the husband does not have the right to object to the manner in which his wife manages her wealth, and the husband does not have the right to dispose of the wealth of his wife, except with her consent. ${ }^{375}$ It is clear, therefore, that a woman does not forego any of her property rights by reason of marriage. ${ }^{376}$

\section{The marriage contract}

Besides the duties that flow automatically when parties enter into a marriage, the parties can also regulate their marriage by means of a marriage contract. Before parties conclude a marriage, they may enter into a prenuptial agreement, or taqliq, in terms of which they can agree upon any legal condition or conditions. ${ }^{377}$ The prenuptial agreement may include a condition, for example, that the woman shall retain the right to dissolve the marriage, or that the husband may not marry a second wife during the subsistence of the first marriage, ${ }^{378}$ or that upon marriage they will live in a certain city or country. 379 In essence, the parties can also enter into a marriage contract to regulate their marital assets.

While the marriage contract is usually concluded before solemnisation of the marriage, nothing prohibits spouses from adding new provisions to the marriage contract, provided this is done in writing and attested to by two competent witnesses. ${ }^{380}$ The conclusion of a marriage contract is indicative of the nature of marriage as a contract whereby each spouse has the right to set certain conditions in respect of the marriage, and it also demonstrates the manner in which Islam protects the rights and welfare of the prospective

Doi Women in Shari'ah 147, 162.

372 Bulbulia "Women's Rights and Marital Status: Are We Moving Closer to Islamic Law?" 1983 De Rebus 431.

373 Al-Jibreen Fataawa al-Mar'ah al-Muslimah vol 2 (1996) 674.

374 Ibn Qudaamah Al-Mughni 513.

375 Sa'ad Mawsoo'at Al-Ijmaa Fi'-Figh Al-Islami vol 2 (1985) 566.

376 Al-Tahaawi Sharh al-Ma'aani al-Athaar vol 4 (1994) 352.

377 Alkhuli The Light of Islam 72.

378 Alkhuli The Light of Islam 73.

379 Alkhuli The Light of Islam 72.

380 The Quran ch 5, verse 1. 
wife, by allowing her the right to lay down certain conditions before she signs the marriage certificate. ${ }^{381}$

However, cognisance must be taken of the fact that conclusion of the marriage contract essentially depends on consensus between the parties. Owing to the unequal distribution of power between men and women, the latter may lack the negotiating power, first, to insist that a marriage contract be concluded, and secondly, to insist that certain provisions be included in the marriage contract that will offer them protection during the subsistence of the marriage. In addition to the above limitations in respect of the marriage, where one of the spouses is in breach of the marriage contract, the aggrieved spouse may be reluctant to institute action in a secular court of law to enforce his or her rights.

\section{South African law}

At present, there are three matrimonial property systems that regulate the patrimonial consequences upon conclusion, as well as dissolution, of a civil marriage: in community of property; out of community of property excluding accrual sharing; and lastly, out of community of property including accrual.

\section{Marriage in community of property}

Marriage in community of property is regarded as the default matrimonial property system in South Africa. In other words, couples are deemed to be married in community of property when they enter into a civil marriage, if they have not concluded an antenuptial contract. ${ }^{382}$ Where spouses are married in community of property, they are automatically joint co-owners of an indivisible half-share of all assets and liabilities, irrespective of whether these assets or liabilities had been acquired before the marriage was concluded or during the subsistence of the marriage. ${ }^{383}$ Upon marriage, the spouses' separate estates merge to form a joint estate. ${ }^{384}$ This takes place via operation of law the moment the parties enter into a marriage, and therefore no transfer of movable property, registration of immovable property or cession of rights from one spouse to the other is required. ${ }^{385}$ There are, however, certain assets that are excluded from the joint estate - for example, assets excluded by means of a will. ${ }^{386}$

Administration of the joint estate for spouses married in community of property is regulated by section 15 of the Matrimonial Property Act. ${ }^{387}$ Section 15(1) allows spouses to act independently of each other in respect of the joint estate, except for those transactions specifically excluded by the Act. Section 15(2) and (3) and section 17(1) of the Matrimonial Property Act

381 Alkhuli The Light of Islam 73.

382 S 86 of the Deeds Registries Act 47 of 1937.

383 De Wet $v$ Jurgens 1970(3) SA 38 (A); Mazibuko v National Director of Public Prosecutions 2009 (6) SA 479 (SCA).

384 lbid.

385 Corporate Liquidators (Pty) Ltd v Wiggill 2007 (2) SA 520 (T).

386 Barratt et al Law of Persons and the Family 287-288.

38788 of 1984. 
regulate the position where the consent of both spouses is required. Different kinds of consent are required depending on the nature of the juristic act that the spouses wish to conclude. Other than the juristic acts mentioned in section 15(2) and (3) and section 17, no consent is required for juristic acts not specifically referred to in the Matrimonial Property Act. In terms of section 15(6), spousal consent is also not required for juristic acts concluded by a spouse in the course of his or her trade, profession or business. ${ }^{388}$

The community of property matrimonial property system has far-reaching consequences for parties owing to the fact that as soon as a marriage is solemnised, the principle of joint liability arises, resulting in neither spouse being protected against the other's creditors. ${ }^{389} \mathrm{~A}$ liquidity problem can also arise at the death of one of the spouses as the executor is both entitled and obliged to liquidate some, or even all, of the assets of the joint estate to meet the claims of creditors. ${ }^{390}$ Furthermore, even where the spouses do not have creditors, the surviving spouse may still experience liquidity problems when the heirs' inheritances become due as the executor is authorised to liquidate part, or even the entire joint estate, to meet the claims of the heirs. ${ }^{391}$

\section{Marriage out of community of property and community of profit and loss without the accrual}

The fundamental rule in respect of the matrimonial property system "out of community of property, and community of profit and loss without the accrual" is that there is no merging of estates and liabilities of the spouses as each spouse retains their separate estate. ${ }^{392}$ All assets acquired and liabilities incurred before the marriage was concluded, and everything earned or acquired during the course of the marriage, falls into the separate estate of each spouse..$^{393}$ It is as if the spouses were legal strangers to each other. There is no joint administration of assets, and neither do the spouses require each other's consent when entering into transactions or incurring debts. ${ }^{394}$ However, spouses married out of community of property share mutual duties of spousal support, as well as responsibilities for the expenses of the joint household. ${ }^{395}$ Spouses married out of community of property, however, can become joint owners of property and even joint holders of a bank account. ${ }^{396}$ In contrast to the position of spouses married in community of property, spouses married out of community of property are merely ordinary coowners as their shares in the joint property are divisible and can be sold to third parties. ${ }^{397}$

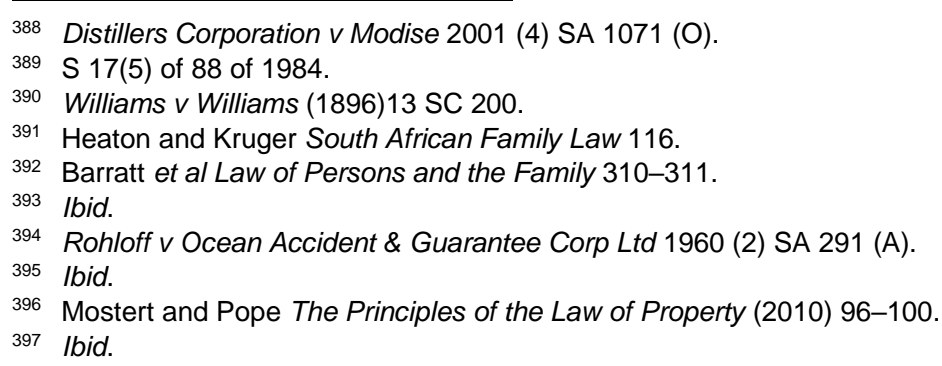


If spouses wish to be married out of community of property, they have to conclude an antenuptial contract before they enter into a marriage. Where the intention of the parties is to keep their estates completely separate, the antenuptial contract must exclude both the community-of-property system, and the accrual system. ${ }^{398}$ In order for an antenuptial contract to be valid against third parties, it must be registered in terms of section 87 of the Deeds Registries Act. ${ }^{399}$

The spouses can include any provision in their antenuptial contract, provided the provision is not impossible, illegal, contrary to public policy or contrary to the nature of marriage. ${ }^{400}$ However, the main objective of an antenuptial clause is the regulation of the spouses' matrimonial property system. ${ }^{401}$

\section{Marriage out of community of property including the accrual}

Section 2 of the Matrimonial Property $\mathrm{Act}^{402}$ provides that the accrual applies to all marriages entered out of community of property from 1 November 1984, unless the parties specifically elected to exclude the accrual system.

The accrual system is referred to as a type of deferred community-ofproperty system as it allows the spouses to retain separate estates during the subsistence of the marriage, but at the dissolution of the marriage, the spouses share in the financial growth that their respective estates have accrued during the course of the marriage. ${ }^{403}$ In terms of section 3(2) of the Matrimonial Property Act, the accrual system allows the spouse whose estate shows no accrual or a smaller accrual than the estate of the other spouse, a share in the estate of the spouse who has a greater accrual, for an amount equal to half of the difference between the accrual of the respective estates of the spouses.

Generally, the accrual claim only arises at the dissolution of the marriage, but section 8 of the Matrimonial Property Act makes provision for immediate division if the conduct of one spouse seriously prejudices, or will seriously prejudice, the other spouse's right to share in the accrual at the dissolution of the marriage. Insofar as the calculation of the accrual is concerned, the accrual or growth of the estate is the amount by which the net value of the estate at dissolution exceeds the net value of the estate at commencement of the marriage. 404

Despite the fact that the spouses retain separate estates during subsistence of the marriage, spouses married in terms of the accrual system must provide for household necessaries pro rata according to their financial

\footnotetext{
398 Barratt et al Law of Persons and the Family 311-312.

39947 of 1937.

400 Ex parte Wismer 1950 (2) SA 195 (C); Hahlo The South African Law of Husband and Wife 259.

401 Heaton and Kruger South African Family Law 83.

40288 of 1984.

$403 \quad S 3(1)$ of 88 of 1984.

404 S $4(1)(a)$ of 88 of 1984
} 
means, and are jointly and severally liable to third parties who supply the household with necessaries. A reciprocal duty of support arises where the parties are married out of community of property, subject to the accrual system. ${ }^{405}$

\section{The law of England and Wales}

Despite the fact that there is no statutory code regulating matrimonial property regimes in England and Wales, the default matrimonial property system is out of community of property in terms of which each spouse retains ownership and control over all his or her own property, whether or not the property is acquired before or during the subsistence of the marriage. ${ }^{406}$ Although the default matrimonial property regime is out of community of property, at divorce, little regard is paid to strict ownership rights when deciding how property should be allocated on the basis of need. Ownership of assets, especially those assets that were acquired before the conclusion of the marriage, may be taken into consideration when deciding how the surplus should be divided. 407

\section{Comparison}

As mentioned previously, in Islamic law, the general rule as far as matrimonial property regimes are concerned, is that marriage is out of community of property with no sharing of assets or liabilities. During the subsistence of the marriage, the spouses are deemed to be legal strangers to each other, and therefore do not require consent from each other to enter into contracts or when incurring debts. In Islamic law, there is also no joint administration of assets acquired by the spouses during the subsistence of the marriage. Similarly, a marriage out of community of property with the accrual is also foreign to Islamic law. The parties can elect to enter into a marriage contract to regulate their marital property in a manner that best suits them. In contrast to the position described above, there are currently three matrimonial property regimes in operation in South Africa, each with its own advantages and disadvantages. In English law, while the default matrimonial property regime is marriage out of community of property, where the marriage is dissolved by divorce, little regard is paid to strict ownership rights.

\section{CONCLUSION}

From the discussion above, it is evident that, while Islamic, South African and English law all attach great importance and significance to the family and to the institution of marriage, these legal systems differ in respect of the legal protection afforded to the family. Islamic law only recognises the family unit that exists within the confines of a marriage. South African and English family law acknowledge that the family unit is much more complex than one

\footnotetext{
405 Ibid.

406 Charman v Charman [2007] EWCA Civ 503 par 124.

407 Ibid.
} 
consisting merely of husband, wife and their children, but is inclusive also of other relationships. As a result, the ambit and scope of protection offered by the South African and English legal systems in respect of the family is extensive as it seeks to accommodate alternative family relationships. A case in point is the legalisation of same-sex marriages.

Furthermore, the adoption of certain international human rights legislation and the enactment of the Constitution dictated that South African family law undergo considerable changes so as to bring the law into conformity with international law, the Bill of Rights and the intrinsic values contained in the Constitution. While the importance of the Constitution as the supreme law of the land cannot be undermined, cognisance must be taken of the fact that the Constitution (and the Bill of Rights in particular) is centred on the individual and based on Western values and philosophies, which are fundamentally different to the principles of Islamic law. The question that needs to be addressed is, therefore, whether Western ideologies should in this day and age be used as the yardstick for marriages concluded in terms of Islamic law.

The fundamental difference between Islamic law on the one hand, and South African and English legal systems on the other, indicates that Islamic law will never completely comply with international equality rights or with the South African Constitution. The conflict between the right to equality, especially insofar as women's right to equality is concerned, and the right to religious freedom will always exist in respect of Islamic law. The fact that Islamic law is fundamentally different to both South African and English law does not make it wrong - merely different. It is therefore imperative that, if South African society is to overcome past discrimination and achieve the vision of equality that is fundamental to a constitutional democracy, the courts, as well as the State, must recognise and promote the full range of diversity that is prevalent in South Africa. This inevitably includes the recognition of Muslim marriages in South Africa. 